\title{
The Society of Artists \& Amateurs, 1834: Toronto's First Art Exhibition and Its Antecedents
}

\section{Carol D. Lowrey}

Volume 8, numéro 2, 1981

URI : https://id.erudit.org/iderudit/1075002ar

DOI : https://doi.org/10.7202/1075002ar

Aller au sommaire du numéro

\section{Éditeur(s)}

UAAC-AAUC (University Art Association of Canada | Association d'art des universités du Canada)

ISSN

0315-9906 (imprimé)

1918-4778 (numérique)

Découvrir la revue

Citer cet article

Lowrey, C. D. (1981). The Society of Artists \& Amateurs, 1834: Toronto's First Art Exhibition and Its Antecedents. RACAR : Revue d'art canadienne / Canadian Art Review, 8(2), 99-118. https://doi.org/10.7202/1075002ar

\section{Résumé de l'article}

La formation de la "Society of Artists and Amateurs ", la première association artistique " officielle » au Canada, témoigne de la croissance rapide de l'activité artistique à Toronto à la fin des années 1820 et au début des années 1830. Une initiative semblable ne se répétera pas avant 1846, avec l'inauguration des "Upper Canada Provincial Exhibitions ». À l'occasion de la première et de la seule exposition, présentée en juillet 1834 dans la salle d'assemblée du troisième Parlement, les membres de la Société ainsi que des personnes de l'extérieur exposèrent des paysages pittoresques, des portraits de personnalités locales, des natures mortes, des scènes historiques et des rendus architecturaux. Le catalogue est typique des premiers catalogues d'exposition par l'absence de matériel descriptif. Par contre, les comptes rendus parus dans le Patriot et le Canadian Correspondent compensent largement cette pauvreté d'information. Non seulement nous procurent-ils une description des oeuvres, mais aussi ils démontrent l'importance des journaux locaux comme instruments de recherche. Malgré l'encouragement et l'appui fournis par le Patriot, la première société artistique de Toronto ne parvint pas à survivre comme institution permanente pour organiser des expositions d'oeuvres d'art. Les frais d'admission et les ventes du catalogue rapportèrent peu d'argent, entraînant des pertes substantielles. Parmi les professionnels qui faisaient partie de la Société, plusieurs quittèrent la ville peu de temps après, en quête d'un milieu plus favorable. En 1847, la "Society of Artists and Amateurs " renaissait sous le nom de « Toronto Society of Arts». Son Comité d'administration se composait uniquement d'architectes et d'artistes professionnels qui établirent un ensemble détaillé de règles pour assurer le fonctionnement de la nouvelle société, puisque l'ancienne association de professionnels et d'amateurs n'avait tout simplement pas fonctionné.
Tous droits réservés (C) UAAC-AAUC (University Art Association of Canada | Association d'art des universités du Canada), 1987
Ce document est protégé par la loi sur le droit d'auteur. L’utilisation des services d'Érudit (y compris la reproduction) est assujettie à sa politique d'utilisation que vous pouvez consulter en ligne.

https://apropos.erudit.org/fr/usagers/politique-dutilisation/ 


\title{
The Society of Artists E Amateurs, I 834: Toronto's First Art Exhibition and Its Antecedents
}

\author{
CAROL D. LOWREY
}

Art Gallery of Ontario, Toronto

Despite its brief existence, the Society of Artists \& Amateurs retains an important place in Canada's artistic heritage when viewed in its role as our first 'official' art society. That it predates the Montreal Society of Artists by thirteen years reflects not only the rapid growth of artistic activity occurring during the late 1820 s and early 18305 , but also an increased interest in the fine arts in general, coupled with a strong desire for a culturally recognized Upper Canada. Toronto's more influential and well-educated citizens were adamant about 'creating a taste for the Fine Arts' within the community. As well, younger artists such as Paul Kane, who went on to make a significant contribution to Canada's art historical tradition, were afforded an opportunity to expose their work to the public eye. Similar opportunities were not again available until 1846 , which saw the first Upper Canada Agricultural Society Exhibitions and, shortly after, the re-emergence of the Society of Artists \& Amateurs as the Toronto Society of Arts.

By the nature of its membership and the works of art exhibited, the Society of Artists \& Amateurs reflected not only the artistic activity prevalent in Toronto during the 1830 os but a strong desire to emulate the British tradition in both the concept and structure of the 'local' art society. Indeed, few people realize just how closely exhibitions in Canada were linked to societies or institutions at such an early date and how frequently these fledgling efforts were undermined by circumstances and even by poor management.

The first and only exhibition of the Society of Artists \& Amateurs is a case in point. An isolated event in Upper Canada, its roots went back to
England, where the tradition of the local art society presenting exhibitions on an annual basis had been established shortly after the turn of the century. Towns such as Birmingham, Newcastle, Bath and Liverpool were not only producing their own artists but providing them as well with the education, patronage and support which had been absent in the past. Large public exhibitions were, by the late $1820 \mathrm{~s}$, common to at least twelve major centres, each with its own bevy of artists, amateurs, collectors, patrons and dealers. ${ }^{1}$ By the early $1830 s$, similar institutions had been founded in the United States, in centres such as Boston, Philadelphia, New York and Charleston. That this phenomenon should suddenly have appeared in Upper Canada at such an early date is remarkable.

In 1793 , John Graves Simcoe $\left(175^{2-1} 806\right)$, the first Lieutenant-Governor of Upper Canada, founded the Town of York. The increase in the number of inhabitants throughout the first years of the city's history was, however, minimal; at the end of the War of 1812 , the population numbered only $700 .{ }^{2}$ It was not until the mid-1820s

\footnotetext{
1 See Trevor Fawcett, The Rise of English Protincial Art: Artists, Patrons and Institutions Outside London, I800-I830 (Oxford: Clarendon Press, 1974), for a thorough discussion of the tradition of the local art society in Great Britain. 'T he author wishes to acknowledge Prof. Patricia Fleming of the Faculty of Library Science, University of l'oronto for her initial advice and support when I delved into this topic (wo years ago. I would also like to thank Karen McKenzic and Prof. W. McAllister Johnson for their contimuous support throughout this project, and Robert Stacey, who read the manuscript and generously provided advice and information.

2 York. Minutes of Town Meetings and Lists of Inhabitants, I $797-1822$
} 
that York underwent a noticeable increase in population. Spurred on by a wave of English emigration, the population had by 1828 increased to 2,325 inhabitants. $^{3}$ By 1834 , the year in which York became incorporated as the City of Toronto, it had jumped to $9,252 .{ }^{4}$ The influx of immigrants continued and by the late $184 \mathrm{os}$, Toronto's population had swollen to nearly 25 ,000 inhabitants. While the city's earliest citizens consisted of individuals connected with the government as well as a number of lawyers, doctors, soldiers, labourers and some merchants, the rapid increase in population which occurred in the late 1820 s and early 1830 os culminated in the rise of a strongly ambitious and articulate middle class, and, as the majority of immigrants came from England, the firm entrenchment of British standards and traditions within the community.

In conjunction with these developments grew the desire, on the part of this newly-established middle class, for self-improvement and the subsequent formation of organizations, societies and spheres of social activity that reflected similar institutions in Britain and were intended to dispel any sense of a frontier character. In December of 1830 , for example, the York Mechanics' Institute was founded and in 1831 the Literary and Philosophical Society, an upper class Tory organization which, although it lasted only one year, intended to provide both a museum and library for public use. ${ }^{5}$ Of these two initial attempts at

3 Public Archives of Canacla, R.C. 5, B26, Statistical Returns. 4 Ibid.

51830 also saw the opening of York's first museum. Its kceper was William Wood, an Englishman who at one time was employed at Charles Willson Peale's museum in Philadelphia. His collection consisted of stuffed animals, wax-works and various curiosities. It was put up for sale in March of 1832 , following Wood's clecision to retire. According to Henry Scadding's Toronto of Old (Toronto: Adam, Stevenson \& Co., 1873), $4^{8}$, Wood's museum was situated at the White Swan, an inn located near the public market.

6 Robert Ford Gagen, Ontario Art Chronicle (undated typescript. E.P. Taylor Reference I.ibrary, Art Gallery of (Ontario), 5. These bazaars continued until about $1_{3} 6$. See: Upper Canada Gazette, 21 A pril 18.36 .

7 Pilkington served on the staff of John Graves Simcoe from 1793 until 1796 and was stationed at both York and Newark (Niagara-on-the-Iake). Many of his sketches of views of Lpper Canada were copied by Flizabeth Postuma Simcoe $(1766-1850)$. For additional biographical information about early Canadian artists, see J. Russell Harper, Early Painters and Engravers in Canada (Toronto: University of Toronto Press. $197(0)$ and the Dictionary of Canadian Biography (Toronto: University of Toronto Press, 1966 - ).

8 York Gazette, 30 A pril 1808.

9 Coates also worked as a portrait painter, choirmaster and organ builder. In 1831 he moved to Trafalgar Township, near Oakville, Ontario, where he took up farming and opcrated a mill. self-improvement, only the former with its more popular orientation, survived and was eventually taken over by the Toronto Public Library in 1883 .

With respect to the fine arts, one of the first organized events to promote the work of local artists was the York Annual Bazaar which, under the patronage of Lady Colborne, wife of the Governor-General, was held in May of 1830 . According to Robert Gagen, these bazaars featured the exhibition and sale of pictures. ${ }^{6}$ Although such events were of a charitable nature (the proceeds being forwarded to institutions such as the Society for the Relief of Strangers in Distress or the local church or hospital), the inclusion of works of art by local artists both professional and amateur indicates that there was a certain amount of artistic activity in the city and that this activity was encouraged and, to some extent, promoted.

Artistic activity in York was practically nonexistent before the late 1820 os. Although a number of British officer-artists such as Robert Pilkington $\left(1765^{-1} 8_{34}\right)$ brought the Woolwich tradition of topographical painting to Upper Canada, these men were frequently posted to other centres after a short time and consequently made no lasting contribution to the city's artistic heritage. ${ }^{7}$ Itinerant artists from both British North America and the United States also passed through York, yet failed to have any long-lasting effects upon the fine arts. Mr. Bouker (fl. 1807-14) for example, a silhouettist from the United States, passed through York during the spring of 1808 and, after taking all the silhouettes he could, went on to practice his art in Kingston, the Niagara district and at various centres throughout Québec, the Maritimes and New England. ${ }^{8}$ It was itinerant artists however who dominated the town's art scene at the time; the lack of an established bourgeoisie, which would have required portraits as well as lessons in drawing and painting, long frustrated the development of a local artistic climate. Indeed, many of York's earliest resident artists were sign-painters by trade or church-decorators who painted pictures, usually portraits, as an additional source of income. Artists of this type included E. Bates (fl. 1818 ), a sign painter working out of an office on King Street, and Richard Coates (1778-1868), a relative of Sir Joshua Reynolds, who settled in York in 1817 and is known primarily for the decorative panels he produced for the Sharon Temple (Sharon. Ontario) shortly before $1828 .^{9}$

During the 1820 s and into the 183 os the number of artists active in York grew in conjunction 
with the increase in immigration from the British Isles. They varied not only by artistic training and style but also by their 'professional' or 'amateur' status. Those having aspirations towards professional recognition were usually required by economic circumstances to ply a varied trade: John Craig (1804-1854), for example, is designated a 'Portrait, Fancy \& House painter' in the 1837 city directory. ${ }^{10}$ Similarly, Paul Kane $(1810-1871)$ is listed in the York Commercial Directory ... $1833-4$ as 'Cane, Paul, Coach, Sign and House-painter, 158 King-street. ${ }^{11}$ His rise to prominence as a 'professional' is seen by the fact that in Brown's Toronto General Directory for $185^{6}$ he is listed under the classification 'Artists' as 'Kane, Paul, 5 Wellington Buildings, King-street east. ${ }^{12}$ Others, such as John Howard (1803-1890), worked as professional architects, or operated lithographic firms, as did Samuel Tazewell (fl. $1823-38$ ). During this early period most artists moved freely and comfortably between the fine and applied arts.

Since many of York's early artists were selftaught, their work frequently displayed the 'primitive' and 'naïve' qualities associated with folk art. This is true of many of the itinerant painters who worked in the city, such as Nelson Cook (1817-1892); while others, such as John Linnen (fl. 1860) and Grove Sheldon Gilbert (1805-1885), produced paintings of a more sophisticated nature, having been exposed to a formal art education in England. Kurope or the United States. With the exception of American itinerant painters such as Cook and Gilbert, York's early artists were generally of British extraction and worked in the dominant British style. Their proliferation during the late 1820 s and early 1830 s was the direct result of the political, economic and social stabilization of both York and Lpper Canada. By 1834 , York had changed from a village to a city and ranked behind only Buffalo and Rochester as the third largest centre on the Great Lakes. ${ }^{13}$

The existence in York of an organized group of artists with the intention of holding exhibitions on an annual basis was first made known to the public via a letter to the editor of the Patriot appearing in the issue of 31 January 1834 . The letter, signed simply 'Instigator, ${ }^{14}$ revealed that, at a 'numerously attended' meeting held a few days earlier at the Freemasons Hall, Captain Richard Bonnycastle (1791-1847), a commander in the Royal Engineers who was also an author and amateur painter, was called to the chair of the 'Artists and Amateurs of York. ${ }^{15}$ The writer went on to report that His Excellency the
Governor-General was to be invited to serve as Patron and Dr. John Strachan $\left(177^{8-1867)}\right.$ ), then Archdeacon of York, was likewise called upon to act as Vice-Patron.

The letter also indicated that Toronto's first art society was to be modelled on similar 'local' organizations in Britain, the writer claiming that, to the best of his knowledge, the objectives and resolutions of the group were 'similar to those of Suffolk street and other Galleries at home' and were therefore to include exhibitions on an annual basis as well as the presentation of various awards and prizes. Thus, at the time of its foundation, the society was seen as a permanent exhibiting organization - a concept not again put into use in Canada until 1847 , when the Society of Artists \& Amateurs was revived (as the Toronto Society of Artists), and the Montreal Society of Artists was formed.

The 'Instigator' then proceeded to inform his readers that contributions to these annual exhibitions would be accepted from Amateurs resident in both York and elsewhere, and that these individuals might 'annex what initials they please to the pictures four of which entitled them to a free admission for the season.' He went on to state that the Association at that time consisted of ' 18 or 20 members, and about the same number of Amateurs,' and that 'the members are bound to send not less than Eight Pictures, although the Amateurs cannot send more.'

In concluding this lengthy missive, the author appealed to the populace for its support of this new organization and its efforts to obtain recog-

10 George W'alton, The City of Toronto and the Home District Commercial Directory and Register with Almanack and Calendar for 1837 (Toronto, U.C.: Printed by T. Dalton and W. J. Coates, 183 (i)?

11 George: Walion, comp., York Commercial Directory, Street Guide and Register, I 833-4 (York, U.C.: Printed by Thomas Dalton, 18.3.1). The spelling of 'Kane' as 'Cane' is probably the compiler's error. The ' $\mathrm{K}$ ' is used consistently in later Toronto directories.

12 Brown's Toronto City and Home District Directory, I 846-7 (Toronto: Printed and published by George Brown, 1846).

13 Important reference sources for those intercsicd in studying the history of York during these years include Edith G. Firth's The Tozon of York, 18 I $_{4}^{-1} 834:$ A Further Collection of Documents of Early Toronto (Toronto: Champlain Society for the (jovernment of Ontario, Lniversity of Toronto Press, 1966 ) and Frederick H. Armstrong's "Ioronto in Transition: The Emergence of a City, $18_{2} 8-18.38$ ' (Ph.D. dissertation, Liniversity of Toronto, 19()$\left._{5}\right)$

${ }_{14}$ The author was probably Charles Daly (1808-1864), an amateur painter who served as City Clerk from $18: 35$ until 1864 . He held the post of Secretary for the Society and it is his namc which is attached to all later announcements and documents pertaining to its affairs.

${ }_{15}$ Daly also makes a point of mentioning that Bonnycastle was a godson of the Swiss-born painter Henry Fuseli (spelled 'Fusclic' in the letter) 


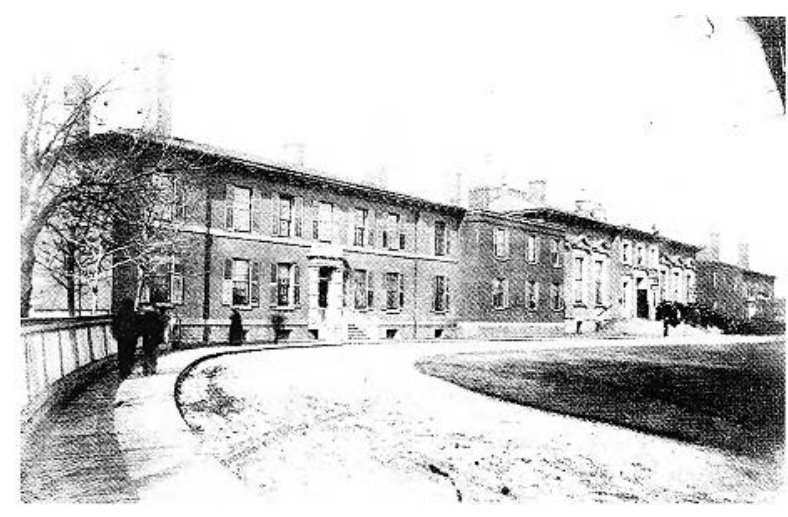

nition in the arts for Canada. Such recognition, according to the author, would aid in eliminating the much-detested epithet of 'Little York' which, as Scadding points out, was frequently used by Americans when referring to Toronto. ${ }^{16}$ In an appeal to the patriotic mind, the 'Instigator' closed with the following remarks:

Let those among us who have energies now dormant or unknown, awake and fecl them ... Why should sciences and arts be only on the other side of the Atlantic, or the Ontario? Why should talents be confined to home? ... Lct them, the talented, unitc in one concentrated effort; let them apply themsclves unanimously with their whole heart, their whole energies to one undivided object, the credit of their country; let the wealthy assist them with their influence and their voice - let them throw aside all party feeling, all party prejudices and antipathies ... and unite in common defense, when the common welfare is at stake, and shall not we? and in a few years perhaps shall not have, as well shall not deserve the epithet of IITTILE YORK.

The citizens of York next heard of the Association through an announcement placed in the Patriot by its Secretary, Charles Daly, informing them that:

\footnotetext{
1 () Scadding, 223. The term 'Litule York' or 'Muddy Litule York' was one of the reasons the city was renamed Toronto in 18,34 (although one finds that 'Toronto' was used as early as the 1820 ; see Scadding, 211 ).

17 I'atriot, York (Toronto), 14 February ${ }_{18} 34$.

18 See the Act to extend the Limits of the Town of York; to erect the said Toum into a city; and to Incorporate il under the name of the City of Toronto, 4 Will. IV, C. 23 for which Royal Assent was granted on 6 March 1834 .

I9 William Carey, Observations on the Primary Object of the British Institution and of the Provincial Institutions for the Promotion of the Fine Arts (N'ewcastle: P. J. Hodgson, 1829), 3.

20) Carey. 23-24
}

FIGURE: 1. Third Parliament Buildings, Toronto. Exterior vicw, 1884. Metropolitan Toronto Library (Photo: Metropolitan Toronto Library).
THE IXXIHBITION FOR THE, PRISSENT YFAR WILL. BE. OPFNED on the ist. of July next. Pictures intended for Exhibition must be sent in during the weeks previous to the $15^{\text {th }}$ of June, and no Picturc will be received after that day. The Comttee [sic] will advertize a month privious [sic] to the time of sending in, where the Pictures are to be directed to. Amcteurs [sic] having four, Pictures exhibited will be entitled to a free admission for the season. ${ }^{17}$

In these initial references, one finds the organization referred to as the 'York Artists and Amateurs Association.' Following the incorporation of York into the City of Toronto in March of 1834 , the Association henceforth became known as the 'Society of Artists \& Amateurs of Toronto.'18

From its very formation then, the Society was faced with the manifold problems of organizing its first exhibition. William Carey, writing a few years earlier, had emphasized the importance of securing appropriate exhibition space, stating that a 'hired' room was undignified and would thus defeat the goals and objectives of the exhibition, namely the 'increase of patronage and professional emulation ... of British works of art. ${ }^{19}$ He went on to declare that a local habitation is the most dignified, and the most certain means of attaining the primary object for the promotion of the Arts,' but that a 'public building for Annual Exhibition, ought to be the immediate object of any flourishing town or city, anxious to ... [promote] the Fine Arts. ${ }^{20}$ Obviously, the Society of Artists \& Amateurs was in no position to erect a building specifically for exhibition purposes; it did, however, select exhibition rooms that would have met with Carey's approval: the Assembly Chamber in the east block of the third Parliament 
Buildings on Front Street, near the city's waterfront (Fig. 1). ${ }^{21}$

Other factors involved in organizing the exhibition necessarily included the transport and hanging of the pictures; advance publicity; and rules and regulations concerning the hours of entry and the sale of individual works. Pictures doubtless were delivered to the Parliament Buildings by their creators, with the actual hanging being done by the Committee of Management. This, according to the catalogue, consisted of Messrs. Castle, Gilbert, Hamilton, Howard, Laing, Linnen and Daly. Indeed, John Howard's diary entries from late June describe visits to the Parliament House two, often three times a day, frequently in the company of Linnen and Hamilton. ${ }^{22}$

With respect to advance publicity, the Society relied on both word-of-mouth and prior announcements in the Patriot. As with most provincial exhibitions in Britain, the official catalogue might not have been readied until some time after the opening date; thus its importance as a means of advance notice remains negligible. Such catalogues did, however, make known various rules and regulations governing these societies and their proposed constitution while providing information regarding the sale of works in the exhibition, opening hours to the public and the price of admission and, most importantly for us, the names of the exhibitors and their pictures.

Next in importance came the opening festivities. While British institutions frequently arranged lavish formal dinners to commemorate the openings of exhibitions, their Canadian counterparts apparently took a more modest route. John Howard reports that during the afternoon of July 1, the opening day of the exhibition, he met the Governor-General in the exhibitions rooms shortly after lunch and returned to work later in the day. ${ }^{23}$

A total of 196 works were exhibited by both members (seventeen are listed in the catalogue, but not all actually submitted works) and nonmembers of the Society. ${ }^{24}$ Differentiation in status was indicated in the catalogue by typographical means - the names of members or 'Associated Artists' being printed in Roman capitals, while those who 'followed the profession' were asterisked. Among the members of the Society, several figures ultimately emerged as avid promoters both of their organizations and of the fine arts in general.

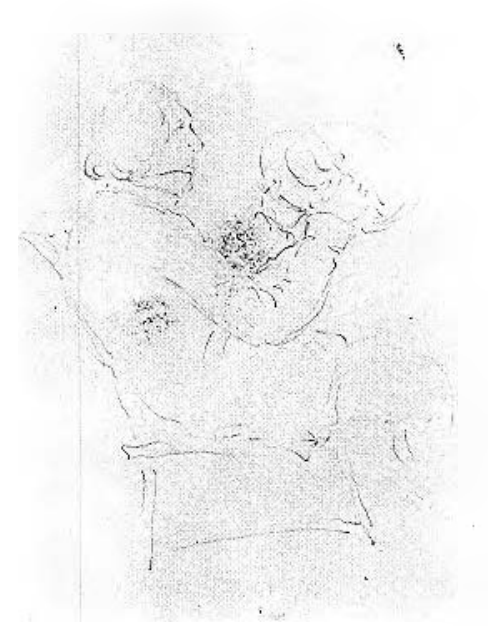

Figurf, 2. Paul Kane, Charles Daly Sketching. Pencil, $232 \times 140 \mathrm{~mm}$. Toronto, Royal Ontario Museum, Inv. 946.15.142 (Photo: Royal Ontario Museum).

Charles Daly (Fig. 2), who held the post of Honorary Secretary, was obviously a driving force in both the founding of the Society and the promotion of its interests. Born in Ireland, he received his education in Belgium and France and, following this, worked as a librarian in the London Athenaeum. After emigrating to Canada, he taught watercolour drawing in Toronto and in 1835 became City Clerk, a position he retained until his death.

The Society's President, Richard Bonnycastle, came to Toronto in 1833 as a commander in the Royal Engineers. During 1837-39 he commanded

21 Following the burning of Government House by American troops in April of 1813 , the Parliament of Lpper Canada sat in numerous quarters, all of a temporary nature, until 1818 , when a new brick building was constructed on the same site. This edifice survived until 1824 , when an overheated chimney flue caused its accidental destruction by fire. The government was then moved to the new buildings of the Gcneral Hospital at John and King Strcets. In 1829 , James $G$. Chewelt was commissioned to erect a new building to be locatcd on Front Street, facing lake Ontario. Completed in 1832, it was constructed of red brick with stone trim. Contemporary illustrations frequently include a four-columned portico which was never built.

22 Metropolitan Toronto Library, John G. Howard Papers. 23 John G. Howard Papers.

24 According to Fawcett, 122, any number of works lower than 100 was considered inadmissible by English standards. 
Higerl: 3. George D'Almaine, Portrail of John Howard while Surveying

the Harbour, 1835 . Watcrcolour and ink on paper, $\left.55^{(}\right) \times 43^{8} \mathrm{~mm}$. Toronto Historical Board.

I)'Almaine painted the figure whilc Iloward painted the background in which he included his design for a Government House (Photo: Toronto Historical Board).

Figlerl: 4. Thomas H. Stevenson, John George Howard, 1848.

Watcrcolour over pencil on paper, $15^{0} \times 130 \mathrm{~mm}$. Toronto Historical Board (Photo: Toronto Historical Board).
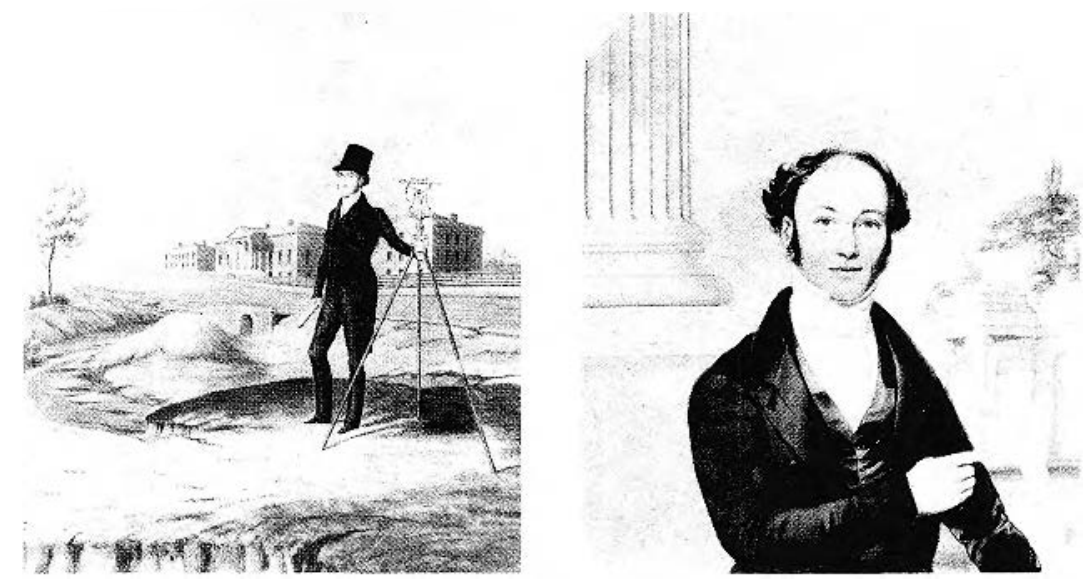

the Royal Engineers for all of I Jpper Caniada and in 1838 was knighted for his services in the 1837 Rebellion. He was the author of several books on Canada and this interest in Canadian subject matter extended into his art - of the scveral artists contributing to the $18_{34}$ exhibition who took an interest in Canadian images, Bonnycastle was (Fig. 9) indeed the most prolific, submitting several works of this genre.

Another enthusiast, whose considerable influence on the development of art societies in roronto was not really felt until the late $1840 \mathrm{os}$, was John George Howard, an architect and painter who arrived in Canada in September of ${ }_{18} 32$ (Figs 3 and 4 ) ${ }^{2.5}$ During February and March of 1833 he competed with six others for the post of Drawing Master at Upper Canada College. He assumed his duties on April 1 of that year and retained his position there until $1855^{6}$.

2.5 For further biographical details, see the l Ioward Papers as well as his Incidents in the Life of John (;. Howederd, Esquive, of Colborne Lodge, High P'ark, with a Catalogue of Paintings in the Picture (iallery (Toronto: Copp, Clark \& Co., 1885). Rescarchers using the Howard material should be aware of the fact that the autobiography was written during the author's old age and frequently contains information which contradicts that which appears in his diaries.

26 lecter from (harles Daly to John Howard, \& Fobruary 1834 . The letter is in the collection of the Public Archives of Canada, R.(;. 5. Al. Upper Canada Sundries, 1. 138 , $75372-75375$. The author wishes to thank Edith Firth, formerly of the Canadian History Section at the Metropolitan loronto library for making this information arailable.

27 Rowan acted as ciril and military secretary to Sir John colborne from 1832 until 18.39. Ile was appointed Commander-in-(hief in British North Amcrica in 18.t9 and during $1853-5+4$ served as Administrator of Canada.
He was also employed as an architect and civil engineer and, in 1850 , was appointed Architect and Surveyor of Buildings for the City of Toronto. Among his designs are the Chewett buildings, Toronto's first of fice block (183.3) and the Provincial Lunatic Asylum (Toronto, 1848 ). He also served as both Vice-President and Ireasurer of the short-lived Toronto Society of Arts $\left(18,7-4^{8}\right)$, and in 1873 donated one hundred and twenty acres of what is now known as High Park to the City of 'Toronto. On his death the City also received the remainder of his property, including his house, Colborne Iodge, which contained his private art collection (now administered by the Toronto Historical Board).

Howard was one of seven men to sit on the original Committee of Management, although his presence there was at one time threatened. He scems to have been an illegitimate child, his mother then marrying a certain Mr. Corby, whose surname Howard carried as a boy. During his Atlantic crossing however, he decided to assume his natural father's name and so arrived in York as a 'Howard.' When this change of name came to the notice of his fellow Committee members, his honesty and integrity were questioned. He promptly reccived a letter from the Secretary stating that the Committee was 'desirous of knowing if you would fecl inclined to offer them any satisfactory explanation ... or if you would prefer retiring from the Committee. ${ }^{26}$ Howard immediately responded with a letter addressed to Lieutenant Colonel William Rowan $(1-89-18-9)^{27}$ explaining the reasons for changing his name 
and declaring that his conduct would bear the 'strictest scrutiny,' going on to include a list of individuals in England who would be willing to provide character references. ${ }^{28}$ In reply to Daly's suggestion that he resign from the Committee and take part only as a member, Howard retorted that if he was unworthy to sit on the Committee, he was equally unworthy to be a member. Since his name does appear among those listed in the catalogue as forming the Committee of Management, his letter of explanation must have been deemed satisfactory. As an exhibitor, his contributions for the most part consisted of detailed architectural drawings, some of which were re-exhibited in the 1847 exhibition of the Toronto Society of Arts (Fig. 10).

In addition to Howard and Daly, Charles Fothergill $(1 ;-82-1840)$ also played a significant role in the promotion of both the arts and sciences in Upper Canada. An amateur painter (Fig. 5), he was also King's Printer of Upper Canada as well as editor of the Upper Canada Gazelte (1822-26). While representing Durham County in the Legislative Assembly of Upper Canada between 1824 and 1830 , he on several occasions voted against the administration; it was this demonstrated independence that helped cost him his posting as King's Printer (he was dismissed by Sir Peregrine Maitland in 1826 ). In 1837 he founded the Palladium of British America, a journal he edited until his death.

Fothergill was also a keen student of natural history; many of his notebooks, the earliest of which dates from 1816 , are now housed in the library of the Royal Ontario Museum and in the Thomas Fisher Rare Book Library of the University of Toronto. Coming from a Quaker family distinguished in the fields of art, science and medicine, he had, by the age of seventeen, published his Ornithologia Britannica, a work dealing with various species of birds common to the British Isles. ${ }^{29}$ Following his arrival in Canada in 1817 , he visited Rice Lake, near Peterborough, Ontario, where he depicted much of the local scenery in a watercolour technique reminiscent of the British landscape painter Richard Wilson.

Scadding describes Fothergill as a "man of wide views and great intelligence, fond of science and an experienced naturalist' as well as a 'skilled delineator of the living creatures that so much interested him. ${ }^{30} \mathrm{He}$ also remarks on Fothergill's misfortune to have lived too early in Upper Canada. ${ }^{31}$ Apparently Fothergill's schemes and plans for the development of Toronto's cultural life were many; owing, however,

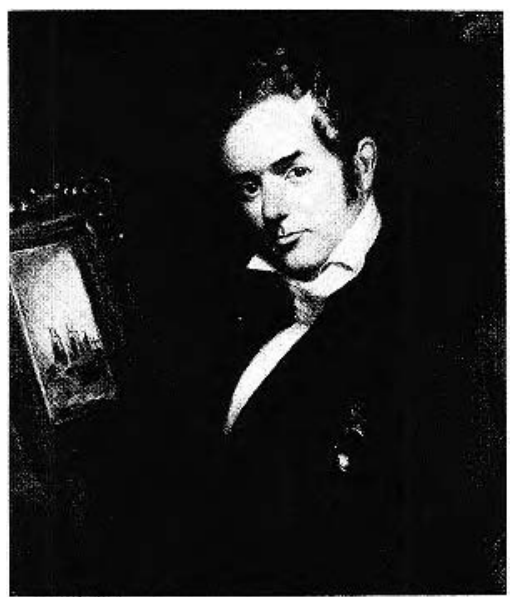

FIGURE 5. Grove Sheldon Gilbert, Charles Fothergill, 1834 . Oil on canvas, $737 \times 610 \mathrm{~mm}$. Toronto, Royal Ontario Museum, Inv. 960.12. Exhibited as Portrait of a Gentleman in the ${ }_{1834}$ exhibition, n" 107 (Photo: Royal Ontario Museum)

to apathy and a lack of support from influential members of the city, they never materialized. Along with William 'Tiger' Dunlop, John Strachan and William Rees, he helped to found the short-lived Literary and Philosophical Society in 1831 . In 1835 he set forth a comprehensive prospectus for the establishment of Toronto's first museum of natural history, which was to have attached to it a picture gallery intended especially for 'subjects connected with the Science of Natural History, and Philosophy, and Portraits of eminent Individuals. ${ }^{32}$ A second version discussed the role of this institution as a provincial museum. ${ }^{33}$ Although a grant of land on the Gov-

28 I etter from John Howard to William Rowan, 11 February 18.34. Public Archives of Canada, R.G. 5, Al, Upper Canada Sundries.

2 () For further details relative to Fothergill's life and work, see J.I. Baillie, Jr., 'Charles Fothergill, $1, \gamma_{2-1} \mathbf{8}_{4} 0$,' Canadian Historical Review, xxv (1944), 376-396. The Ornithologia Britannica was published in York, England, in 1799 .

30) Scadding, 209 .

31 Scadding, 210

32 Charles Fothergill, Proposed I.yceum of Natural History, and the Fine Arts, in the City of Toronto, U.C. (Toronto: W. J. Coates, 1835).

33 Charles Fothergill, Second Address Relative to the Proposed Lyceum of Natural History, and the Fine Arts, in the City' of Toronto, U.C. (Toronto: W. J. Coates, 1836 ). 


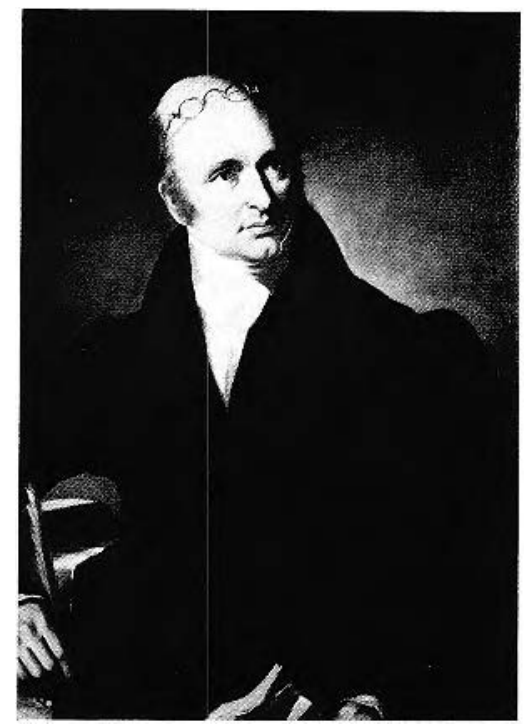

FIGURF. 6. Anonymous, Thomas

Dalton. Oil on canvas, $784 \times$

$956 \mathrm{~mm}$. Toronto, Archives of

Ontario, Inv. 853

(Photo: Archives of Ontario).

34 Fothergill's private collection, which would have formed the nucleus of the muscum's permanent collection, was first displayed in the Chewett buildings, located on the southeast corner of King and York Streets. It was later moved to a site in the Market Square building (now the St. Lawrence Hall). Its destruction occurred at a location near the corner of York and Boulton (now Pearl) Streets, near the Palladium office.

35 Mary Allodi, Printmaking in Canada: The Earliest Vieus and Portraits (Royal Ontario Museum, Toronto, 18 April - 25 May 1980$),\left(91-(9)^{2}\right.$

36 Indeed. the Patrint praised Tazewell for introducing York to the 'sublime art of L ithography ... with so praiscw'orthy assiduity' on several occasions. Tazewell also supplicd an engraving of Walter Scott, after Maclise, for the Canadian Literary Magazine which appeared in April of 1833 (this periodical was printed by Thomas Dalton, edited by John Kent and published by George Gurnett; the only other issue produced was that for May of 1833). Commenting on the Scott portrait, Kent referred to it as the first we belicve ever engraved in Upper Canada - engraved too on (anadian Stone, and from thence, by means of a Canadian press, transferred to Canadian paper.

37 Tazewell's firm depended primarily on government orders to keep it in business. When James Chewett becarne the provincial draughtsman and surveyor in 18.35 . Tazewell's services were no longer utilized.

$3^{8}$ John Gamble (1799-1873) was a manufacturer and politician who settled on Mimico Creek in Etobicoke, Ontario, around 1823 . For a comprehensive study on Kanc's life and career, including a catalogue raisonné of his works, see Harper's Paul Kane's Frontier (Toronto: University of Toronto Press for the Amon Carter Museum. Fort Worth, and the National (Ballery of Canada. Ottawa, 1971). Harper, 270 , suggests that the depiction of Gamble's house might possibly be the landscape entitled Rural Ontario Farmhouse with Bridge in the collection of the Royal Ontario Museum, Toronto (Inv. 94(0.15.310). ernment Reserve between the Garrison and Farr's Brewery was secured as a site for the Lyceum in 1836 , funds for the actual construction were not forthcoming and Fothergill's ambitious scheme never did materialize. His own natural history collection however was on display in Toronto from about 1835 until 1840 , when it was destroyed by fire shortly after his death. ${ }^{34}$

Samuel Oliver Tazewell, Upper Canada's first lithographer, was also a member of the Society. Following his emigration to British North America during the early 1820 , Tazewell settled in Kingston, Ontario, where he worked as a drygoods merchant, watchmaker and jeweller. He became interested in lithography during the late 1820 s and, according to Mary Allodi, was probably the author of an article dealing with the technical aspects of lithography which appeared in the Kingston Chronicle on 24 November $1830 \cdot{ }^{35} \mathrm{He}$ moved to York in the fall of $183^{2}$ and there founded the 'York Press,' where he proceeded to print regional maps for the office of the Surveyor-General. While in Upper Canada he received much encouragement from Thomas Dalton (1792-1840), editor and owner of the Patriot and Farmer's Monitor (Fig. 6). ${ }^{36}$ In 1835 he moved to St. Catharines, where he returned to his former occupations of watchmaking and jewellery. ${ }^{37}$

Further members included John Linnen, a professional portrait and figure painter who had originally studied at the Royal Scottish Academy in Edinburgh; Samuel Waugh (1814-1885), an itinerant artist from Mercer, Pa., who lived in Toronto during 1834 and 1835 (and who later acquired a reputation in Philadelphia for his Italian panoramas); Grove Sheldon Gilbert, another American who received his artistic training at Middlebury Academy; and John Popplewell (f1. 1833-41), an Englishman whose background included the teaching of mezzotinting, japanning and painting on velvet in Québec. Although Paul Kane was also a member of the Society, he, like Tazewell, was not designated a 'professional' in the catalogue. It is possible that he was regarded as a student by his peers (he would have been twenty-four at the time) and that his occupation as a 'Coach, Sign \& House-painter' denied his being recognized on a professional level. Of the nine paintings he exhibited, eight were copies seven being executed after prints, the eighth after a landscape by Drury. His only original composition was a view of John Gamble's house at Mimico, Ontario (a subject also portrayed by John Laing) (Fig. 8). ${ }^{38}$ 


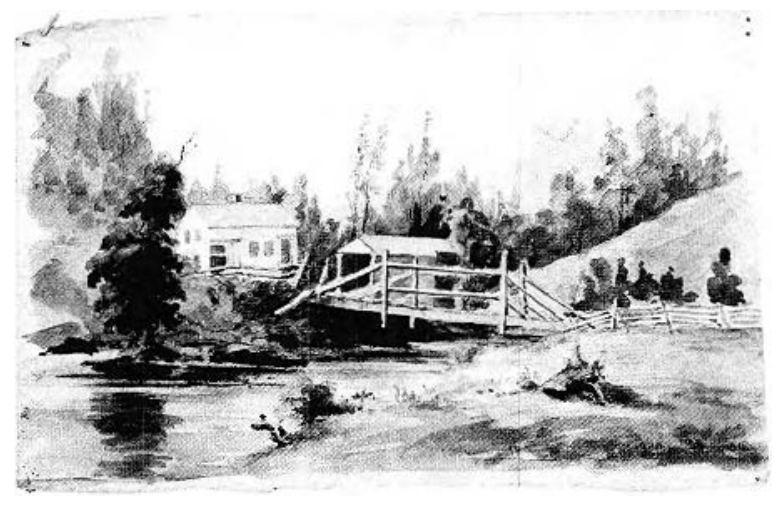

Other Associated Artists included John Craig, an Irishman who, in addition to working as a portrait and sign painter, was a Tory alderman for St. George's Ward, sitting on Toronto's City Council from 1834 until $1849 ;^{39}$ James Hamilton (1810-1896), an accountant at the Bank of Upper Canada who was known for his highly competent landscapes; Lieutenant Jones and Messrs. Overend and Steers, who for one reason or another failed to submit any pictures; John Laing (f1. 18:34) and Henry J. Castle (fl. 18:34), both amateur painters; and Thomas Drury [or Drewry] (fl. 1834 - ca. 1871 ), a drawing master at Lpper Canada College known to have given lessons in drawing and painting to Paul Kane.

Included among the non-members were Jemima Howard (1802-1877), John Howard's wife; ;0 Henry Bonnycastle (1814-1888), the son of Richard Bonnycastle; Thomas Dixcec (fl. $1828-65$ ), who arrived in York early in 1834 and immediately advertised his services in the Patriol as a 'Portrait, Landscape, Figure and Flower painter,' and William Connell (fl. 1834-37), a local engraver with a studio at $15^{2}$ King Street who was responsible for engraving John Craig's design for the City Seal. William Kay (fl. 1833-34) exhibited several landscapes of European origin while George D. Wells (fl. 1834) submitted works portraying both the landscape and Indians of British North America as well as renderings of Lower Canadian costume. Perhaps the most notable exhibitor not actually belonging to the Society was Nelson Cook, an itinerant painter from Boston who worked in Toronto as a professional portrait artist during $18,34-38$. He achieved notoriety in Toronto in 1837 when the local citizen's committce sent his portrait of Sir Francis Bond Head (now in the National Gallery of Canada) to
Figurf: 7 . Paul Kane, Ontario Farmhouse with Stream and Bridge. Watcrcolour over pencil, $140 \times 232 \mathrm{~mm}$. Ioronto, Royal Ontario Museum, Inv. 946.15.310. Thought to be the Residence of John Gamble from the 1834 exhibition, n" 116 (Photo: Royal Ontario Muscum).

England to be translated into a merzotint which Queen Victoria, displeased with Head's handling of the 18.37 Rebellion, refused to have dedicated to her. ${ }^{41}$ Both Cook and his wife were listed in the 18.37 city directory as portrait painters at 106 King Strcet West. Cook later worked at Saratoga Springs, New York $(1841-44)$ and in Rochester, New York $\left(185^{2} ; 1856\right)$, and periodically returned to Toronto in order to undertake

39 A triplet window of stained glass which Craig designed for St. James Cathedial, Ioronto, was destroyed when that building burned down in 18.39 .4 s a member of the city's first Council, Craig sat, along with ('eorge Gurnetl, on onc of three committees set up to deal with matters resulting from the Incorporation. This particular committec was responsible for chosing a design for the city seal. Craig, a sign and heraldic painter by trade, likely produced the design himself and awarded the actual engraving of the seal to William Conncll, a fellow I rishman (much to the displeasure of William Lyon Mackenzic, who would have, according to the review's of the exhibition, preferred 'somc republican artist in Now York'). Conncoll's impressions werc included in the 18,31 exhibition but were exhibited separately, being 'distinct from the gencral design.' for further information. sce Barrie Drummond Dyster, "loronto 18.10-18(60): Making It in a British Protestant 'Town,' 2 vols. (Ph.D. disscrtation, Lniversity of Toronto, $19-(0)$, and (arol I). I.owrey, 'John Craig,' Dictionany of Canadian Bingraphy, vol. vil (forthooming). Victor L. Russell, (ity of l'oronto Archives, was extremely helpful in providing information concerning Craig's involvement with the city seal.

10 The 183.1 catalogue lists all fernale exhibitors as "A lady.' Jemima Howard's participation in the exhibition is made known by the fact that this document was reprinted in 18,8 , probably by her husband. The reprint edition records her name in seven instances. It also reproduces a letter from (harles Daly to Mrs. Howard, inviting her to submit pictures to the exhibition (see: (harles Daly, Hon Sec. to Mrs. John Howard, 7 June 18.3.1, John (;. Howard Papers).

fl the portrait of Bond Head by (eorge Berthon

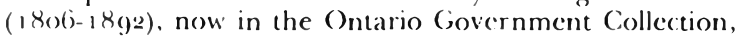
was copied in $188_{3}$ after the mezotint in question. 
various commissions. In 1847 he submitted a number of works to the April exhibition of the Toronto Society of Arts. Other exhibitors disguised their identity as 'A Lady' or 'A Gentleman' or revealed their youthfulness, as did 'Masters' Tazewell (probably Samuel Tazewell's son) and Hurd.

In all likelihood, visitors to the 1834 exhibition would have encountered the type of exhibit characteristic of provincial societies in England. Works in oils and watercolour predominated, while prints, sculpture and other works were seen in lesser number. The majority of subjects were picturesque landscapes (Tintern Abbey being an obvious favourite), with local portraiture following closely behind. The remainder consisted of still lifes, historical scenes and architectural renderings. Many of the paintings were copies after works by Old Masters (Salvatore Rosa, Velasquez) which were probably known through prints. Despite the predominance of pictures portraying subjects from the British Isles and Europe, one cannot ignore the inclusion of works dealing with local and regional subjects; Bonnycastle and Tazewell, for example, both contributed several views of Niagara Falls, while Kane and Laing submitted renderings of John Gamble's house in Mimico. George Wells' pictures of the Indians of British North America would have added another dimension to this growing interest in Canadian subjects.

Since works could be submitted up until 15 June 1834 , the printing of the Toronto catalogue had to await the compilation of a final list of exhibitors. Catalogues produced by British societies tended to be octavos or quartos of approximately twenty to forty pages within paper covers. Most included a short introduction or preface outlining each institution's objectives as well as the current rules and regulations. Patrons and donors were also listed. The majority of catalogues consisted of a simple numerical listing of

\footnotetext{
42 The original catalogue, measuring $22.9 \times 18.4 \mathrm{~cm}$, is a pamphlet consisting of eleven pages and one leaf. The only copies extant are, to our knowledge. located in the Baldwin Room, Metropolitan Toronto Library, and the City of Toronto Archives.

13 Edith Firth's Early Toronto Newspapers, I793-1867 (Toronto): Baxter Publishing ( $($ )., in co-operation with the Toronto Public Library, $19(61)$ provides an annotated list of all known Toronto weekly or frequently published periodicals in existence during those years. One might also consult W. S. Wallace, 'The Periodical Literature of Upper Canada,' Canadian Historical Rerizew, XII (1031), 4-22.

44 A bi-weekly publication, the Patriot was not able to continue its review on the 1 ith of July due to the "crowded state' of that issue.
}

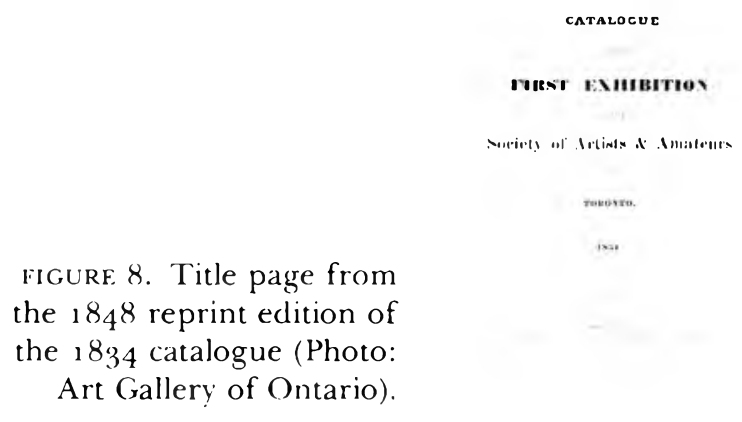

the works along with the artist's name. Indeed, the early exhibition catalogue was not looked upon as what it has since become - the remaining record of a single event and a point of reference for future research and exhibitions. Hence, it tended to lack descriptive detail such as the date of execution and dimensions of individual pictures.

The catalogue produced for the inaugural exhibition of the Society of Artists \& Amateurs illustrates this early type of publication. Printed at the office of the Patriot, it contains, in addition to a page naming the various patrons, officers and members, a listing of the works and the names of their creators. This is followed by an index including the names of both Associated Artists and Honorary Exhibitors. A second edition of the catalogue (Fig. 7) appeared around 1848, probably at the instigation of John Howard. ${ }^{42}$

The paucity of descriptive information in the 1834 catalogue is more than compensated by the reviews from the Patriot that appeared throughout the duration of the exhibition. It is to these sources that the researcher must turn, since they not only provide us with some idea as to what the works actually looked like, but also illustrate the nature of art criticism of the day. In like manner, they testify to the importance of local newspapers as research tools, for, during the 1 gth century, they were certainly the principal medium of information and communication in Upper Canada (in the case of Toronto's first art exhibition, they were used to announce both the Society's formation and its forthcoming show). ${ }^{43}$

The reviews in question (reprinted here as Appendix I) appeared in the Patriot on the $4^{\text {th }}$, 8 th, 11 th, 22 nd and 29 th of July. ${ }^{44}$ Each work was discussed singly or as part of a group of 


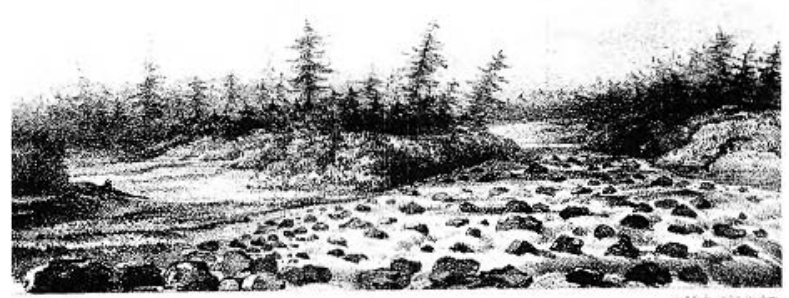

FIGL'RE: 9. Richard Bonnycastle, White Trout River, Trinity Cove, Labrador Coast, from his The Canadas in $184 \mathrm{I}$ (London: George Colbornc, 1841). After the work in the 1834 exhibition, n" $13^{8}$ (Photo: Public Archives of (anada).

related works according to the sequence in which they were listed in the catalogue. The reviewer, presuming that his readership was, for the most part, unskilled in matters pertaining to taste, produced reviews of a highly didactic nature. Accurate representation of detail and a high finish were his major concerns.

We can only guess at the identity of the author of these unsigned comments. Thomas Dalton's earlier encouragement of 'Tazewell in Kingston, coupled with the frequent appearance of book reviews and other items relative to the arts in his newspaper, suggest that authorship might well be his since he apparently 'differed greatly from many contemporary editors in having had a good early education. ${ }^{15}$ Dalton was also a staunch supporter of the Family Compact, so his support of an art society with such a 'quasi-official' nature would have fit in well with his Tory outlook. Another possibility might be John Kent $(1807-88)$, a schoolmaster and journalist who arrived in Canada in 1833 and shortly thereafter became the editor of the Canadian Literary Magazine (printed by Dalton and published by George Gurnett). It might possibly have been Kent who penned the favourable remarks concerning lazewell's portrait of Scott, which appeared in the inaugural issue of that journal. ${ }^{46}$

Whoever was responsible for the reviews, it is obvious that he wished to encourage rather than discourage contributors. Disparaging remarks seldom appear. In fact, criticism was quite lenient, although the reviewer did harbour a distaste

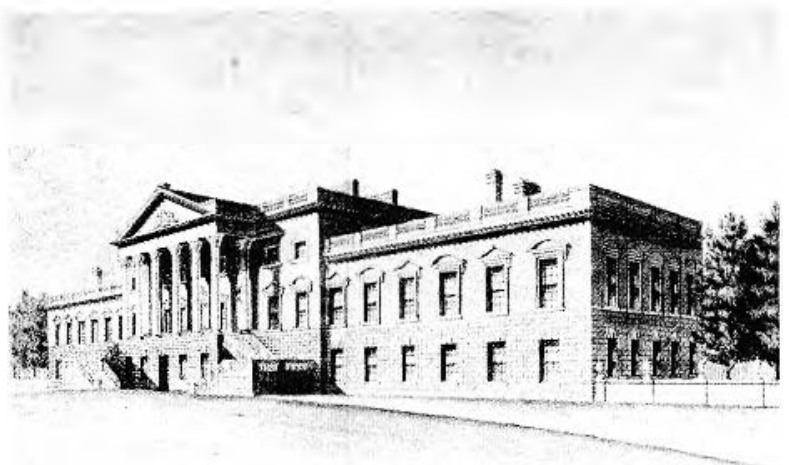

Ficirf, 10. John Howard, Design for a Government House, 1833. Watercolour and ink, $413 \times 630 \mathrm{~mm}$. Toronto Historical Board (Photo: Toronto Historical Board). for what he felt was non-naturalistic colouring or distortion in drawing. ${ }^{47}$ The reviews stress what was then considered the predominant requirement for a successful composition - that it resemble nature.

Whatever the encouragement and support provided by the Patriot, the inaugural exhibition of the Society of Artists \& Amateurs was unsuccessful in its attempt to draw public attention

15) See Raymond Card, 'The Daltons and the Patriot,' Cianadian Historical Review, xil (19:35), $176-1 ; 8$. Dalton, along with Charles Daly, was a member of the British Constitutionalist Society, an organization consisting primarily of Tory editors and merchants. He became widely known for his frequently violent attacks upon William lyon Mackenzic and his Reformers.

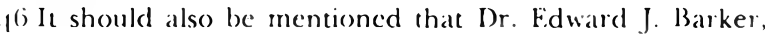
editor of the Kingston British Whitg, made the Toronto exhibition known to his readers, largely through his comments concerning Nelson Cook (who had neglected to advertise in Barker's paper while in Kingston). Referring to the Socicty as an 'infant Royal Academy' he altacked Cook's pictures in particular, describing them as the "paltry daubs which were for some weeks hung up in the sitting room of the Commercial Hotel' (British Whig, 11 July 18 ;.4). Fidently the Patrot revicwer read Barker's comments and retaliated accordingly in his remarks about Cook's sclf-portrait. Sce: Barbara Snyder, 'Velson Cook in Canada.' Canadian Collector, 1 ( September/October 1976): 2()-22.

17 This lenient attitude on the part of our reviewer did not go unnoticed, as revealed in a latter to the editor of the Canadian Correspondent (9) August 1 83.1). The author, who chose to remain anonymous, challenged both the critical knowledge of the Patriol's revicwer as well as the artistic abilitics of several of the exhibiting artists, Grove Sheldon (iilbert in particular. This Ied to a spirited exchange betwecn the (wo writers whose leters are reprinted as Appendix II. 
to the fine arts. A cholera epidemic had recently struck the city; this, coupled with the intense heat of July, discouraged citizens from venturing forth to visit the exhibition. Admission fees and catalogue sales were low, so substantial monetary losses were incurred. In an attempt to relieve some of the debt, Richard Bonnycastle presented a series of paid lectures later that year. ${ }^{48}$

As a result, the Society failed to survive as a permanent exhibiting organization; the financial losses were substantial enough to have dispirited its members, several of whom, such as Waugh

$4^{8}$ Thesc lectures were advertised in the Patriot, 11 November 18.3 .1$.

49) Patriot, 12 September 183.4.

50 The Toronto Society of Arts, to which we will return in a subsequent article, was also short-lived, holding only two exhibitions during 1847 and 18.4 . I ike its predecessor, it too was based on British models. The two catalogues extant reveal a well-formulated set of rules and regulations and a morc ambitious programme of activitics, including the establishment of a collection of plaster casts as well as classes in drawing. Its membership consisted of both artists and architects, the latter group making up the greater proportion. lixhibitions were held in 'Toronto's Old City Hall, and the presence of reviews in both the Globe and the Examiner indicates a wider responsc on the part of the press and Tazewell, left the city shortly thereafter. Following the exhibition, Thomas Dixcee raffled eight of his works in order to obtain the funds necessary to return to England. According to an insert in the Patriot, Toronto was 'as yet too young to afford his profitable employment. ${ }^{, 49}$ Thus, despite the fact that artistic activity in the city was on the increase, support for a resident population of artists was limited. One must consider, too, the possibility that the newly-established City of Toronto was simply not ready for such an 'institution,' the pursuit of culture likely being very low on the priority-list of the average citizen. Also, the Society was of a quasi-official nature - the 'best' of Tory Toronto - and its patrons and members consisted primarily of gentleman artists still very much aware of class distinctions and political affiliation (Toronto at the time held a Tory Legislature and a Reform City Council). It was also quite possible that a combination of Sunday painters and professional artists simply did not work. In 1847 , when the Society was reborn as the Toronto Society of Arts, the Committee of Management consisted solely of practicing artists who devised a detailed set of resolutions on which its administration was to be based. ${ }^{50}$

\section{APPENIDIX I}

Whatever the real importance of listing the contents of Toronto's first art exhibition, it is of far greater importance and intercst to emphasize the criticism arising therefrom. The (unsigned) revicws appearing in the Toronto Patriot have therefore been adopted as the basic text and are given in chronological order. Since the reviews are necessarily selective in nature, entries from the exhibition catalogue itself have bcen footnotcd and are kcyed to the critical texts, thereby providing a complete, if composite, record of the event. Spelling and punctuation are reproduced as given, while the typographic distinctions of the original catalogue have been observed, with capital letters for Associated Artists and asterisks for the professionals.

\section{Toronto Patriot, Friday 4 July 1834 FINE. ARTS}

We were admitted on Wednesday last to a private view of the exhibition of pictures \&c. now open to the Public in the East wing of the Parliament Housc. That there should be resident in this young (ity talent sufficient nearly to fill three of those rooms is truly astonishing, and it does Mr. Daly the Honorary Secretary infinite credit for bringing those works together, and presenting them to the public. He has the hearty thanks of the Artists and Amateurs, \& descrves well of the public for procuring them such a mental treat. There are Portraits by Messrs. Gilbert, Waugh, and others, that would not disgrace the name of the Royal Academicians of london, and Landscapes by Messrs. Dixcee, IIamilton \& Kane, that possess all the freshness and beauties of Naturc. The Honorary President Capt Bonnycastle, shincs in the ruins of Tintern Abbcy. These are ruins indeed enveloped in air, you may walk round \& under them, screened from the scorching rays of the Sun. There is pure light and shade, wrought on true philosophical principles. Well did the Artists evince their judgement in requesting such an one to become their President. There are many beautiful specimens of architectural drawings by $\mathrm{Mr}$. Howard, we wish we could sce our city cmbellished with their realities. We shall take an carly occasion to visit the exhibition again, and to venture our opinions on the merits of the several performances; meanwhile we strongly recommend to the public to avail themselves of the opportunity thus for the first time afforded of enjoying so exquisite a treat. The Hours of exhibition are each day from I0 A.M. to 5 P.M. - Admittance 1s. 3d. Tickets for the season 5 s.

\section{Toronto Patriot, Tuesday 8 July 1834 [cat. 1-26] FINE ARTS.}

Agreeably to our expressed intention we proceed to give our opinion of the specimens exhibited in the numerical order, in which they occur in the rooms.

South West Room. 
No. I Wild Rose, Charles Fothergil, very natural and pretty, but rather tame, wants shadow.

2 Royal College of Elizabcth Guernsey, Master Hurd, shows talent for a youth.

3 Shrine at Thiers, Henry Bonnycastle, a drawing in chalk, small in size, but large in merit, particularly bold and spirited. showing great knowledge in light and shadc. Mr. Bonnycastle having evidently the capacity to become a great painter should study in Oil, and with the utmost diligence.

4 Brecon Castle, Henry I. Castle, free and bold but wanting in breadth of light.

5 Fishermen on a coast, after Tomkins, Charles Daly, beautiful arrangement of color, and spiritedly pencilled.

6 Lower Canadian Costume, G. D. Wells, we think we recognise in this a copy from an admirable original by Capt. Young of the $79^{\text {th }}$

7 Coast Scenery, storm coming on, good again Mr. Daily, we feel it coming and shall take to great coat and umbrella.

8 Study from Canova's Helen, H. Bonnycastle, this gentleman's fort is I.andscapc.

9 Four bold and agrecable sketches in pencil which have all the freshness of color. - William Kay.

10) Group of Natural History, Fothergill, beautiful transcripts of the Originals.

11 to 18 Sorne very agreeable studies. ${ }^{1}$

19 Sketch of an old mill in Wales, by Dixcee. On this though of bold execution, we must not waste words, as we have observed this artist to have works in the exhibition demanding special and elaborate eulogy.

20) to $2 j$ Several objects of interest, all presenting something to admire. ${ }^{2}$

26 Entrance to a Cathedral with Beggars from a Print, Laing. Admirably drawn: fine effect of light, but the shadows not sufficiently clear and rich. This gentleman has a true taste for the fine arts, which he should improve by studying and painting from nature in Oil.

To be continued.

Toronto Patriol, Friday 11 July 1834

[cat. 27-100]

\section{RFMARKS ON THE ARTISTS EXHIBITION OF PICTURES CONTINUED.}

\section{SOUTH WEST ROOM}

No. 27 Flowers from Nature, Mr. Popplewell, very cleanly painted and transparent, but not sufficiently relieved.

28 Strect views in Schaffhausen on the Rhine, Charles Daly, very rich and bold, and beautifully coloured.

$29 \& 30$ Dewerston Rocks and Torquay, Laing, inost sweetly penciled, but we greatly regret to see such exccllent talents wasted on such intense yet perishable labors. Mr. Laing, hie thee to ()il, and the all conquering Brush.

31 Interior Ruins of 'Tintern Abbey, Capt. Bonnycastle, President. Of this charming picture we have before spoken, but have seen it again with renewed delight. It is a chaste and striking picture, and excellently calculated to display the powers of judiciously disposed light and shade.

$32 \& 33$ Seven Miniatures, Mr. Lockwood, the only, and very masterly specimens in Miniature; bold and spirited in a high degree, and chaste and elegant in coloring. Mr. Lockwood might probably enlarge his subjects with advantage.
3.1 A group of Beggars in Pcncil, Saml. B. Waugh, excellent expression but rather hard.

$35 \& 33^{6}$ Two more of $\mathrm{Mr}$. I.aing's exquisite pencillings. ${ }^{3}$

37 Coast Scene, Mr. Daly's studies evince all mind, we should like to see a little more body. At the next exhibition, we trust he will show more finish.

3 lilowers, Popplewell. The lulip in this group is painted with eminent skill. Rich, tender, and aerial. It is rare to see a more beautiful approach to nature.

39 to 57 Sundry objects of interest displaying various degrecs of taste and skill, none are without merit, and some display considerable ability. ${ }^{4}$

$5^{8}$ Design for a Mansion for a Military nobleman, John $G$ Howard. Mr. Howard is rich in design, and it would appear excentric in fancy. The Mansion in an opulent country, genial clime, and well chosen sitc would be an enviable residence for a wealthy nobleman whether Military or Civil.

59) Winchelsea Gate, H. Bonnycastle, an exceedingly spirited sketch. But if Mr. Bonnycastle have not recourse to ()il, he will bc like the flower, which,

'Unseen,

Wastes its sweetness on the desart air.'

(6) Fall of the Mynach from the Devil's Bridgc, H.J. Custle. A pleasing Scene, but this gentleman wants brcadth of light through all his works to give them life and vigor

$\left[61-(i 2)^{5}\right.$

b.3 Residence of Chief Justice Robinson, Toronto, Laing, faithful to reality, and tenderly pencilled.

(i) A Calm, Howard. Effective, but hard.

1 'These 'very agreeable studies' consisted of: 11 Sketch of the ruins of the ancient Pictish Fort at Culswick in Letland CHARl.Fs Fotmikcill.. 12 Chepstow Castle - HFing J. casiti. 13 A Brecze, after Copley Fielding - chari.Es DAl.Y. 14 Lower Canadian Costume - George D. Wells. 15 A Skctch - CIIARLt.S DAI.Y. 16 Two Sketches - Master Tazeziell. 17 A nondescript specics of Godwit - CHARI.ES VOTIIR RGII.I. is Canal diggers pumping - Henry Bonnycastle.

2 This group included : 20 Whirlpool Niagara, from below Capt. Boninycisti.t. Prest. 21 Four Gems - *William Connell. 22 Flowers - A Lady. 23 Roses - Master Hurd. 24 Kildare Abbey, from a Print-joHiv taING. 25 Vicw of the cclebrated cradle of Noss - CHARLF.S Follitergili..

3 According to the catalogue, both drawings werc entitled View in Devonshire from a print.

4 This group included: 39 Saint Marc's Square, Venice, from a print - *JOIIN G. HOWard. 40 L'Aumore, a market place in France, from a print - JOHN G. IIOWIRD. 11 Cards - Master IIurd. 12 $^{2}$ Flowers - *JOHN POPPLEwiti. 13 Interior of Tintern Abbey from a print - JoHN I.ANG. 14 Bird-catching on the North Western coast of Fula -

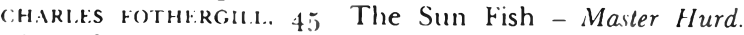
46 A Sketch - Master Tazewell. 47 A Landscapc-George I). Wells. $4^{8}$ A Design for a Church - *Jomx c. How IRD. $19 \Lambda$ Landscape - George I). Wells. 50 High Road to Rhayardogowy - HWRY J. CASTI. jl Thane Market, Oxford, from a print - HENRY J. CASTl.F. $5^{2}$ Waltham Abbcy - HiNRY J. CASTIF. -3 Sketch, - An Amateur. 54 Sketch. - An Amateur. 55 Six l.ithographs from Canadian Stonc, - s.o. IAztwit.. 56 Flowers, - An Amaleur. $57 \wedge$ Butterfly, - An Amateur.

5 l'hese works were listed as: 61 Sketch, - Master Tazewell. (i2 $\Lambda$ Lady, - George D. Wells. 
65 The Perce' Bay of Chaleurs. Capt. Bonnycastle, a very beautiful geological drawing.

$66^{3}$ to 8 ; Sundry pieces of fancy, displaying in many instances much merit. ${ }^{6}$

$g^{6} \quad$ [recte $8(j]$ Sketch of Helmsley Bridge and Castle lower, Yorkshire. Charles Fothergill. A calm sober drawing, showing much knowledge of the (hiaro-scuro, and what may be effected by neutral tint alone.

$[8-7-(9) 1]^{7}$

$92 \& 95$ Entrance of Jupiter River, and the White Cliffe Anticosti, Capt. Bonnyrastle. Two superb geological drawings.

$[9.3-() .4]^{\mathrm{H}}$

$g^{(j) ~ N o r t h ~ A m e r i c a n ~ I n d i a n ~ C h i e f . ~(; . ~ I) . ~ W e l l s . ~ O f ~ t h i s ~ y o u n g ~}$ gentleman's productions we may say generally, that he displays the capacity of becoming, with study, a fine artist. He is passionately fond of colors: but this, in a tyro, we consider a beaty rather than a blemish. Contemplation of Nature sub. dues passion, and practice reaches to blend and harmonize.

97 to 100 four pleasing objects of considerable merit. ${ }^{9}$

I hus, to the best of our ability, have we completed our strictures upon the contents of the First Room. Two objects yet remain to be spoken of, which, being distinct from the general design, we have neglected till now to mention. These are - a ladies' Work-Table by Mr. Popplewell, and four ('ems, impressions of engravings on metal by Mr. Connell. which attest the admirable skill of the artist; on whose arrival and domicile with us, we congratulate the City. Mr. Connell is a

6 These consisted of: 66 Bala Lakes. - Haxy J. Casme. 6i Wild Duck Shooting, - A Lady. In the reprint edition of 18.18 , Mrs. Howard's name is used in lieu of A Lady. Subscquent appearances of her name as found in the later catalogue will be indicated by the use of square brackets. 68 Perspective vicw of the U.C. College, Toronto, - *om (i. IIOWARD. 6g White Fronted Tern, - charals Fothrtall. - io Street View in England from a Print, -

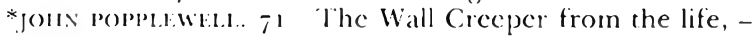
chartis rothrocill... 72 Intcrior of lintern Abbey, IINRy f. castif: 73 View in Venice after Prout. - foms

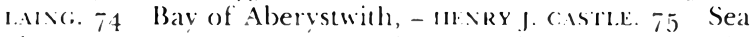

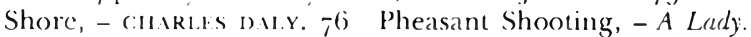
[Mrs. Howard.] it Fall of Niagara from the Ferry, - *Joris 6. How Amcrican Indians, - George D. Wells. 8o Chinese Painting,

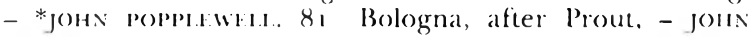

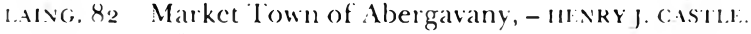
$8: 3$ Banks of a River near the Sea, - chatrlis Daty. 8. Woodcock Shooting, - A Lady. [Mrs. Howard.] $8_{5}$ Design for a Church, - *Jorix (i. HOW IRD).

7 This group included : $8_{7}$ Residence of John Gamble, Fsq., Mimicoke Creek, - joll Lisc. 88 Trumpeter Pigeon from the life, - cimalis fothlircill. $8_{9}$ An Idea in Perspective, - *JOHN (;. HOWIRI), go Perspective view of the Parliament Buildings, Toronto, with the Portico, - *ors (. H(O)ARD. 91 Cathedral of Munich from a Print, - JoHs 1.+1ive.

8 These works consisted of: 93 Fxterior of Tintern Abbey, -

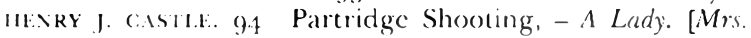
Howard. ]

9 Thesc 'objects of merit' were: 97 Rochester Castle from a

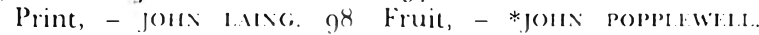
99) Design for a Church, $-{ }^{*}$ Jom (i. IIOWARI). 100 American Fall, Niagara, from the Ferry Rocks, - Capt. BONNYCASTIF, Pres.

10) Although mentioned in the criticism, these items did not appear in the cataloguc.

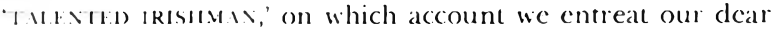
fellow-citions to refrain from persecuting him - of which, alas! there has been already manifested a strong symptom in a HICH quarter; - his lordship having pertinaciously opposed, though happily without effect, Mr. Connell's engraving of the City Seal, which his I.ordship was bent on getting executed by some republican artist in New York, although Mr. Conncll's specimens are demonstrations of perfect mastery of his noble art, and his price the same as of the foreign republican artists. This information we have from members of the Corporation, who properly vindicated domestic worth. Mr. Popplewcll's Work-'Table must be an object of feminine desire in this City of refined taste. In our next, we shall commence with the South-East Room, which, being so rife with genius, we approach with diffidence; but we shall confidently ihrow ourselves upon the mercy of the Artists - and, if we err on our way, we cntreat their candour to believe, that, however defective our judgement, it will be at least sincere. The genuinc artist will not envy another's praise, nor feel his self-love wounded by a candid criticism of his defects, when offered by an admiring friend, with the sole view to their futurc correction. ${ }^{10}$

Toronto Patriot, Tuesday 22 July 1834
[Cat. $101-113$ ]

\section{REMARKS ON THE ARTISTS' FXHIBITION (Continued)}

\section{SOUTH FAST ROOM.}

Vo. 101 Portrait of a Centleman. S. B. Waugh. We do not comprehend the arrangement of this Picture - not being aware of any rule of art, or law of nature, that should cause the figure to be so powerfully illumined, and every thing around, far and near, in darkness. There is nothing in the picturc to account for this. The figure is out of drawing, and appears shrinking within itself from fear or pain. We rccommend Mr. Waugh to reconsider this picture at the close of the Exhibition.

102 Portrait of an Artist. John Linnen. There is a good effect of light and shade, but we think the shadows in the flesh should be more cool and grey, as this would give warmth and richness to the light: and it was the practice of Rembrandt, whom Mr. L. had in his mind while designing this picture. The back of the hand is not incorrectly drawn, and is rather hard in effect.

103 Portrait (By the Same), of Colonel Forster, and somewhat like; but is hard, and the color inclining too much to the olivebrown. The neck is stiff, and ill-drawn. This gentleman should study from the naked figure, or from casts after the antique.

104 \& 105 Interiors of a Convent and Monastery. By a Lady. Two pretty imitations of coloured prints.

ıof Table Rock. Niagara. Captain Bonnycastle. A difficult subject, and we have no doubt correctly delineated; but the water appears a little too much like ice - it wants liquidity.

(1) 7 Portrait of a (jentleman. (i. S. Cilbert. A good likeness of Charles Fothergill, Esq.; very cffective, and well painted, but the attitude rather strained.

$108 \& 109$ Morning and Fivening, from Prints after both. (James Hamillon.) These are charming compositions, and pencilled with admirable frecdom but the colour is not to our tastc, we have seen nothing like it in nature, nor, do we suppose, has the Artist. Let Mr. Hamilton study from nature, and he will be a fine painter. 
110 The Place of Pernes, a Roman Station in Picandy. Copptain Bonnycastle. In this a magnificent breacth of shadow, thrown across the road, conducts the eye very artully into the picture.

111 Portait of Mr. H. (;ilbert, G. S. Gilbert. Of the likencss we know nothing; but, from Mr. (ilbert's felicitous success in other cases, we are bound to presume it a living resemblance of the original. It is a picture of great merit, that would reflect no discredit on any artist living, and certainly confers tho highest honor on so young and sclf-taught an artist as Mr. (iilbert. We were about to saly it is decidedly the best portrat in the Exhibition, but are witheld by the recollection of our weakness of judgment and the great excellence of some others yet to be mentioned, as well of Mr. Gilbert as some others. The expression of the comntenance is mild, animated, and benign; the arrangement of light and shade, and the coloum and handling, are a tout ensemble, bespeaking true genius lacking but opportunity and experience to rise to the highest excellence of the sublimest of all the arts. Could Mr. (Gilbert visit London, where he might study the masterpieces of the world. there can be litule doubt his name would soon be heard of, as ranking among the most eminemt of the london artists

1128113 Two landscapes in ()il. Paul Kane. Very agrecable pictures. ${ }^{11}$

$$
\text { (To be continued.) }
$$

\section{Toronto Patriot, liriday 29 July 1834 \\ [cat. $115^{-195}$, of $19^{6}$ ] \\ REMARKS ON THI $\triangle$ RTISTS EXHIBITION (continued and Concluded.)}

\section{SOLTH EAST ROOM CONTINLLI)}

No. 11, Flowers, from Vature. Thos. Dixces. A bold and effective representation of a Lily and a Rose, giving great cridence of power of hand and knowledge of color.

116 Residence of Jno. Gamble, Esq. Mimicoke Cireck. Paul Kane. This picture possesses much truth to nature, and is tenderly pencilled

$[1,17]^{12}$

118 An Abbey in Ruins. James /lamilton. Well painted but sadly colored - hated and cold. Mr. Hamilton has only to study color to become eminent as a landscape painter. We hope he has the organ of color.

11 !) Sketch in ()il. (iblbert. Very good.

120 Sketch for Skakspeare's Hemry VI. Captain Bonnyerastle. food drawing, but cold in coloring: the back of the man supporting the head of the fallen figure is cxcellent.

$\left[\begin{array}{lll}1 & 2 & 1\end{array}\right]^{13}$

122 Fruit from Nature. Dixces. Bunch of Grapes, Peach, Vectarinc, and Plums, grouped. - An achmirable picturc: the Grapes are as transparent as any seen in nature, and the bloom of the plums is exquisitely represented. It is a choice counterfeit of Pomona's richest gifts.

123 A Ruin. Hamilun. We have said all we need say of this gentleman's productions.

$[1: 2.1]^{14}$

125 landscape after Hobbima. William Connell. This picture displays powers which want but practice 10 render their possessor cminent as a landscape painter; but he is cminent in what perhaps is a morc prolitable art, - for this is the gentleman who is engraving the City Seal, for which we hope the Corporation will paly him a good price, in order lo encourage him to remain with us. This is the really lituNIt) IRISIMIX,

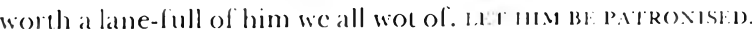

126 Studyafter (uvp).

127 Sketch alier Berghem.

Thomes

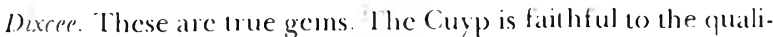
ties for which that great master was cminent, of whom it is historically reported - "He excelled in every article that he attempted to represent, and painted every object in the same free and natmal manner; always lovely and true in his coloning, always (lear and transparent. He was accustomed to observe nicels, cren the particular limes of the day - 10 express the varons diffusions of light on lis objects, with all the truth of nature; and, in his pictures, the morning atcended by all its mists and vapours, the clearer light of noon, and the saffion-colored tints of the evening, maty radily be distinguished.' - The Sketch from Berghem is a Cow's Head, represented to the rery life. The meck creature has just dipped her nose into a meal-tub), and is looking gratitude 10 hor feeder. She is absolutely alive. It is a most valuable linle picture.

$[1,8-1,36]^{1.5}$

137 Lady and Child. Saml. B. Waugh. Woll painted, bul Child's arms out of drawing; the Child's commenance is cxceedingle sprighty and natual. The lady's drapery is excellent.

$\left[1: 3^{x-1} f^{0}\right]^{16}$

1,1 \& 1 f2 Two Rich Architcctural Designs, by Howard (lear and brilliant

$[1+3-150]^{17}$

\section{NORIH ROOM}

1j) Falls of livoli from a Print. Paul Kone. This picture has great merit in many of its parts: the distances are actually a great way off, and the ligures are alive, and busy in their ser-

11 According to the callologuc, Kane's landscapes included: 112 Ilarlich Castle and distant view of Suowdon $X$ Wales, (op) - Pal: Kavi 113 Lake Ceorge affer Drury Pil. I. Kaxi:

12 This was listed in the catalogue as: 117 landscape William $\mathrm{Ka}$ :

13 This was listed in the cataloguc as: 121 film lark, from a Print - PAl: K.INR.

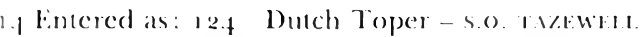

1.) This group included: 128 Sea Shore - J.MIs II.MmION. 129 Pointe a la Cioix \& narrows of the Radstigouche

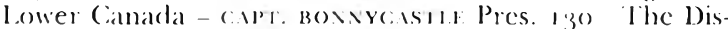

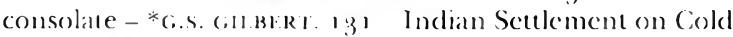

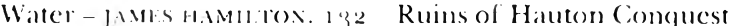

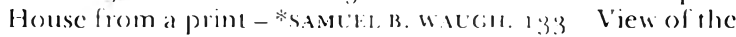
Falls of Viagata from the old Bathing Housc - Capl.

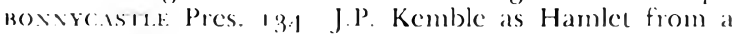
print - *Velson Cooke. 13j lhe Parthenon Alhens from a print - *Jom (. IIOW ARr). 136 lioness and Whelps - s.o l.iviliti.

16 These works included: 138 White liout River, Trinity Corc, labrador Coast - Capd. Boxisycistre, Prest 139 The Souvenir, fiom a print - *as. (ill BlRt. ifo View of the falls of Niagara, from a print - palt K.INE.

17 This group consisted of: 1,3 landscape - jums

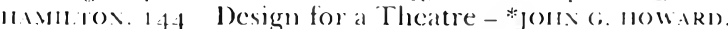
145 The rired Soldici - A lady [Mrs. Howard.] 1 g(j The:

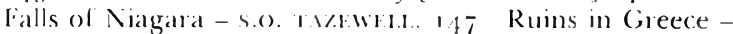

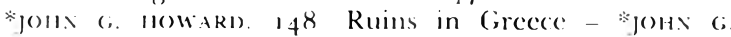
IOWARI). 149 Portrait of a Cinteman - Nelson Cooke.

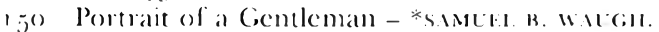


eral vocations. The coloring is, however, upon the whole rather cold. Practice and study would make Mr. Kane an artist of name.

\section{A Mameluke. By the Sume. Very spirited}

153 Portrait of a Child. Waugh. The countenance very beautiful, and expressive of great intclligence. Mr. W. has here shown great taste in coloring.

$\left[1.54^{-1}, 56\right]^{18}$

157 Portrait of a Gentleman. Waugh. A bold and wellstudied picture. Many great masters have not painted as well at the same stage of their progress. We consider this to rank among the very best Portraits in the Exhibition.

$[158]^{19}$

$[159]^{20}$ Portrait of an Artist. Nelson Cooke. This is $\mathrm{Mr}$. Cooke's own Portrait, and is a very spirited and expressive picture, but wants accuracy in drawing. This is one of the pictures exhibited in Kingston which the British Whig called a 'daub'. It is said 'the Wisdom's in the Wig,' and it may be, for aught we know, in Dr. Barker's wig; but, in this instance, it is not very perceptible, and it is said the heart is the seat of kind-

18 These works included : 154 Female Hcad, from a print ${ }^{*}$ G.S. Gillbert. $15 j$ Portrait of a Gentleman - *samufi. B. waU(iH. $15^{6}$ Portrait of a Gentleman - *G.s. CillBi:RT.

19) Entered as : ${ }_{5}^{8}$ Magdalen from a sketch after Carracci Nelson Cooke.

20 Although described in the reviews, the catalogue number was omitted.

21 This group inclucled: 160 Portraits of Twins - * JонN Linnf.N. 161 Portrait of a Gentleman - *Thomas Dixcee. 162 Liberation of the Prisoners from the Bastile - * ${ }_{\mathrm{JOHN}}$ G. Howard. 163 Portrait of a (ientleman, $-*_{\text {(..S. GIL.BIRT. }}$

22 These pictures consisted of : 165 Portrait of a Gentleman, - *samlfi. B. Wacia. 166 Portrait of a Gentleman, *Jolin tinnir. $16 \bar{j}$ - Portrait of a Gentleman, - * do. 168 Portrait of a Lady, - * do. 169 Portrait of a Gentleman, - * do. 1 - 0 Portrait of a Lady, - * do. 171 Portrait of a Gentleman, - * do.

23 This group included: 173 Hardraw liorce, from a Print, - PaUl Kank. 174 Landscape from a Print, - Pall, KaNe. 175 Spanish Toper, after Velasquez, $-{ }^{*}$ G.S. GillBf.RT.

24 A number of portraits which included : 177 Portrait of a Lady, - do. [cat. no. 176 being a work by JOIIN LINNEN]. 178 Portrait of a Gentleman. - do. 179 Portrait of a Gentleman, - do. 180 Portrait of a Gentleman, do. 181 Portrait of a Gentleman, - do.182 Portrait of a Lady, - * Samcil. B. WAUGh.

25 This was listed as: 184 Mercury setting Argus asleep from a print after Salvator Rosa, - JAMI:S HamILTON.

26) Thesc included: 187 Portrait of a l.ady, - *s.Muf.L B. waUcih. 188 Portrait of a Lady, - * *..s. (in.BERT. 189 Portrait of a Lady, - do. 190 Portrait of a Lady, - *SamLf. B. Wituchl 191 Sir Walter Scott from a Print, *Nelson Cooke 192 Portrait of a Centleman, - joHN L.INNR.N. 192 Portrait of a (ientleman, - *Samuli. B. WaUciH. [Intended as cat. no. 193].

27 The final picture listed in the catalogue : 196 Holy Family, after Gulio Romano, - *Thomas Dixcee. ness and gencrosity. We will not judge of Dr. Barker's heart by this single instance of random censure upon a youthful artist, to whom it might be of serious injury could the Dr. by possibility be estecmed a judge.

$[160-163]^{21}$

16.4 Portrait of a Gentleman. Waugh. A very admirable picture.

$[165-171]^{22}$

172 I andscape. Thos. Dixcee. This is a View from Nature, painted in the fields - and, as a Landscape, is decidedly the great gem of the Exhibition. It is a View near Merthyr Tydvil, in Glanmorganshire, and is painted much in the style of the great Jacob Ruysdaal, a celebrated Flemish landscape-painter of the $1 ;$ th century, whose pictures now command astonishing prices. As was said of this great painter by his biographer, so may we justly say of this most charming Landscape - 'The grounds of his landscapes are agreeably broken, his skies are clear, his trees are delicately handled, every leaf is touched distinctly and with a great deal of spirit, and every part has the look of true nature.'

$[173-175]^{23}$

176 Portrait of a Gentleman. John Linnen. This is a good likeness of $\mathrm{Mr}$. Sutherland, and very prettily painted.

$[177-182]^{24}$

18.3 Portrait of a Lady. G. S. Gilbert. A very agreeable Picture of a very beautiful young lady.

\section{$[184]^{25}$}

$185 \& 186$ Two Portraits of the Honourable William Drummer Powell, Late Chief-Justice, and his Son Grant Powell. Esq.; by Gilbert. Both admirable likencsses and skilfullypainted picturcs, - but we prefer by far the picture of the Judge, which will be hereafter esteemed by the family an invaluable treasure. Grant Powell's, we know, is most esteemed by some, to whose judgement perhaps our own ought to defer; but, de gustibus non dispulandum.

$[187-19.3]^{26}$

194, 195 Two little Sea-Pieces - Sketches in Oil: Very clever. Mr. Connell.

$[1,96]^{27}$

We now respectfully take leave of the Gentleman Artists for the present season, and much do we regret to understand that they are likely to be considerable losers by their laudable efforts unless the public visit their Exhibition during the next four days of the present week, after which we are informed it will close. We had hoped there was sufficient taste among our citizens to insure at least remuneration for the unavoidable expense of making so rich a display of their admirable works. We trust the Artists will belicve we have endeavored to be just in delivering our opinions upon their performances. They will perceive we can have been guided but by one motive that of encouraging the Arts by cherishing the Artists. We have at least satisfied our own consciences that we have been directed solely
Pro Bono Publico. 
At the close of the exhibition, critics representing two Toronto newspapers exposed their views concerning the nature of art criticism as well as the artistic merit of some of the exhibitors. This polemical exchange seems to have been based on the differing political colouration of Dalton's Patriot, which acted as the voice of the English Conservatives, and the Canadian Correspondent whose editor, Father William John O'Grady, was well-known for his opposition towards the Family Compact. These exchanges, whatever their political overtones, appear to be among our earliest examples of controversy relative to the nature of art production and criticism, with particular emphasis on the role of copies after Old Masters. The three letters are here reprinted in chronological order. Spelling, punctuation and typography are reproduced as given. When the identification of a work is secure, the original catalogue numbers of Appendix I are intercalated. The letter appearing in the Patriot of 15 August 1834 , which was consulted in the Baldwin Room and used for the microfilm now in circulation, has a minor defect resulting in the loss of a number of words. Such omissions as may occur, have been indicated by [ ].

\section{Toronto, Canadian Correspondent, Saturday 9 August 1834}

\section{(FOR THE CORRESPONDENT)}

Sir - In glancing over the 'Patriot' of July 22 , I found there a criticism on certain pictures then exhibited in the East Wing of the Parliament Buildings. The critic commences his remarks upon the portrait of a gentleman by $\mathrm{Mr}$. Waugh [101], but rather unfortunately for the picture he "cannot comprehend the arrangement, not being aware that any rule of art or law of Nature would leave the figure to be so powerfully illumined while every other object was left in uttcr darkness.' He declares 'there is nothing in the picture to account for it:' which proves, at least to my satisfaction. that this critic is not yet acquainted with Rembrant's style of Painting: in which case I would recommend to his notice a few prints after that master: but as it is likely that even then he will not be able to account for the monopoly of light by onc object, for his further information I will endeavour to throw a little more light upon the subject. - It is simply this, that Rembrant's paintingroom was lighted by one solitary ray which was so directed as to fall with force upon the principal object in his piece, and upon no other object in view. But our worthy critic not being possessed of such information could not, of course, retire within himself in search of a cause. It was a most unpardonable neglect of Mr. WatciH not to have stuck a torch in the hand of this portrait as it would have prevented the worthy critic's exposing (in this one instance) his wcakness of judgment and want of information. The next picture in rotation is a portrait of an artist by J. I.NK [1(12], which, according to him, displays a good effect of light and shade: after which acknowledgment he immediately attacks the incans taken to produce the effect. [ ] is in favour of 'cold grey shadows which would warm and enrich the light,' because, says he, it was the practice of Rembrant: what a pity that Rembrant did not hear this remark; it would have tickled him very much as his greatest pride lay in his beautiful, deep, warm shadows. The drawing of the hand, too, offends his correct eyc; but there are other hands in the exhibition that remain to be noticed though not drawn by his paragon of perfection as he has not proved, in one single instance, that he can draw the human hand in any shape. The next is a portrait, by the same, of Col. Foster [103], '\& somewhat like.' 'The olive brown of which he complains is preferable to the color of a brick the neck is stiff, and ill-draw'n, by which remark it will casily be seen that our critic is not of the army, as he would have know'n that it is the pride of a soldier to show that his head stands firmly upon his shoulders 'ill-drawn' - Now whether he means that L.N.v should have developed the muscles of the Colonel's neck through the thick collar of his military coat, I know not: but this I know that there can be no bad drawing where no drawing exists. The Table Rock, - Niagara, by Capt. Bonnycastle [106] 'which, we have no doubt, is correctly delineated, but the water is too much like ice, it wants liquidity.' Mark him 'correctly delineated'! but the water too much like ice, and wants liquidity! In short, it would appear, this would-be critic had been in no want of liquidity (when he pen'd such consummate nonsense) of a stronger quality indecd than that now tumbling over the Table Rock! The next is a portrait of Mr. FoTHERGill. by G.S. cillBR.RT [107], 'a good likeness, but the attitude rather strained,' perhaps he considers it no fault in a portrait to be 20 years younger than the original. Two landscapes by Mr. HAMILTON 'admirably pencill'd: colour not to our taste, nothing like it in nature' $[108 \& 109]$. After such remarks there can remain no doubt that our critic's ideal of nature are of the first order; and, of course, must form a good criterion for painters to study from - the sooner they are issued to the world the better. Another by Capt. Boninycastin: in which 'a magnificent breadth of shadow thrown across the road conducts the eye very artfully into the picturc' [110]. Now, who in the name of common sense, ever heard that the shadows of a picture first attracted the eye when cvery person know's that the eye is first attracted by the light thrown upon any object: in good keeping with all his other remarks. Another portrait by G.S. GIIBFR' "which we are bound to presume a living likeness of the original, after coming from the pencil of such an artist' [111]. Here is a picture held out as a perfect master-piece of art, executed too by a self-taught artist. - How simple it is for a man of genius to rise to the top of the art! - Our infallible critic winds up his criticism by strongly recommending $\mathrm{Mr}$. (G. (o) visit I.ondon, where by studying from the masterpieces of the world his name would soon be ranking among the most eminent of the London Artists; and where, no doubt, as a proof of his supcrior abilities, might become a successful candidate for the President's Chair. Now, Mr. Editor, perahps you are not aware that all this ridiculous extravagance is about an individlual that condescends to copy prints and other men's works, and then endeavours, by the assistance of his friends, to pass them for originals. - In short, all that can be justly said of Mr. (') pictures may be comprehended in a few words: - In the first place be it understood, that he merely draws Heads, and that his method of doing so is partly mechanical. - In the second place his portraits of persons from $3^{\circ}$ to 80 years of age are of 
one and the same colour - failing to produce the different degrees of age by varying the tint; whilc his Femalc Hcads, below 20 , are as flat as the pannel of a door, and in colouring mere milk and water. If he would mix a little of the (Olive Brown among his Brick Dust, he would come much nearer to the human skin.

I hope, Mr. Editor, you will permit me to continue this subject in a future number of The Correspondent.

\section{Toronto, Patriot, Friday 15 August 1834 \\ To the Editor of the Patriot.}

\section{MR. EDITOR,}

In the last Correspondent is a long article bearing all the external appearance of a critique upon a Critique of certain works of art lately exhibited by the Artists and Amatcurs, which it is too evident the writer of has only made the mcans of conveying a most unwarrantable attack upon a descrving young Artist, at present absent from this City. Had he done this while he was here or while the exhibition was open I should not have troubled myself about it, as then the Artist might have defended himself, or the public might have judged for themselves if they thought proper. In the commencement of this tirade, $\mathrm{Mr}$. Waugh's Picture is brought first on the tapis for no other purpose than concealing a little more his evident aim. He here introduces the name of Rembrandt for what purpose is seen in the sequel and talks a great deal of stuff about that great Master, as if it had ever fallen to his lot to be blessed with a sight of one of Rembranclt's Pictures whose name he does not even know how to spell, but I shall bear in mind that good precept 'Nothing extenuate, nor aught set down in malice.' And without making any remarks upon the pictures by other Artists lauded by this writer procced at once to the part that induced me to take notice of this compound of nonsense: - 'Now, Mr. Editor perhaps you are not aware that all this ridiculous extravagance is about an inclividual that condescends to copy prints and other men's works and then endeavours by the assistance of his friends to pass them off for originals; in short, all that can be justly said of Mr. G.'s pictures, may be comprehended in a few words. In the first place, be it understood that he merely draws heads, that his method of doing so is partly mechanical; in the second place, his portraits of persons from 30 to 80 years of age are of one and the same colour, failing to produce the different clegrees of age by varying the tint, while his female heads below twenty are as flat as the panel of a door, and in colouring, mere milk and water; if he would mix a litule olive brown among his brick dust he would come much nearer to the human skin.' All this is not the gentlemanly language of a Critic and person conversant with the art, but the low abusc of an individual who has some private pique to resent or purpose to serve.

Mr. G. when he copied from prints, had the same inserted in the catalogue of the exhibition where it may still be found, if this would-be critic pleases to refer to it, so much for passing off \&c., and if he thinks it a crime to have copied from others, let me tell him that Michael Angelo, Lionarclo da Vinci, Pietro Perugino, Raffaelle, Bartolemeo, Andrea del Sarto, 11. Rosso and Pierino del Vaga, thought it none, nor have the masters of a more modern school, and even Raffaelle went so far as to) copy and pass off for his own. certain figures of Masaccio's, but I suppose all this will be heathen Greek to the writer in the Correspondent as he most likely never heard of such persons. 'Mr. G. merely draws heads, and his method of doing so is partly mechanical.' Mr. G. is a Portrait painter, and his business is to draw heads, and as long as a man minds his business,
I can see no just reason for finding fault with him, especially when, be it known to this sapient critic, that Sir T. Lawrence in the course of his long and glorious career, never attempted above four historical subjects but merely drew Heads, and that Jackson, Shee, Beechy, Phillips, Pickersgill, and various other of our more eminent artists of present \& by gone days 'merely draw or drew heads.' As to the mechanical way of doing it, Mr. G. uses no other mechanical means than those employed by all other Portrait painters if this person knew of any other he should have specified them without making so sweeping an assersion: the rest is all nonsense, - Bye the bye, though, will this person, who ever he is, in the next letter to the Correspondent, tell the public how many portraits of femalc heads below twenty years of age 'he has seen of $\mathrm{Mr}$. Gilbert's' that are as flat as the pannell of a door, and in coloring mere milk and water? I can tell him Mr. G. never painted but one, and whether that is flat or colored like milk and water, must be decided by some one who knows more about Painting than he does, and now for the climax. When a man desends in talking or writing about pictures, to introduce Brick Dust, he show's at once how little of gentlemanly feeling or knowledge of the art pervades what he says or wites, and with this I dismiss the subject, not to return to it unless the Correspondent's correspondent should venture to attack anyone clse in the way he has done Mr. G., which I do not expect, as it is so plain, what this letter was written for.

VINDEX.

\section{Toronto, Canadian Correspondent, Saturday 30 August 1834}

\section{FINE ARTS.}

\section{TO THE EDITOR OF THE CORRESPONDENT.}

SIR, - In pursuance of my previous intention I am again upon the heels of our learned critic, whose remarks are continued and concluded in the 'Patriot' of July 29 .

'Flowers from Nature by 1. DIxci.e.' [1 15 ] (the beau ideal of our critic,) whose praise he sounded as high as the superlatives of the English language would carry him. This artist pretends also to portrait painting, which is evidently a branch he knows nothing about, as his portrait of Dalion proves. In fact, when I compare that picture with the other works exhibited in his name. I cannot divest myself of the idea that they have been painted by different artists. I hope otherwise, however; nor would I have gone so far upon the subject but for the foolish extravagance of our learned critic.

'An Abbey in Ruins by Mr. Ha.MILTON well painted but sadly colored - hard and cold' [ 118 ]. Had our critic intended to show his acquaintance with the technicalities of the art, he should have arranged them so as to exclude the possibility of of their contradicting each other so flatly. How is it possible I would ask, that a picture can be well painted, and at the same time 'hard and cold!' Even people that know very little about painting must see the absurdity of such remarks.

'A sketch in Oil by cil.Bt:RT, - very good' [119]. 'This is one of those copies alluded to in a former number of The Correspondent, and decidedly one of the most incorrect and most paltry of all his copies. In poring over the absurdity of such glaring partiality, I think I have discovered the great error into which our critic has fallen: it now strikes me very forcibly that instead of chosing Nature for his standard, he has, for party purposes, set up Gilbert's pictures for a criterion to go by. Now had our critic inclined to act a friendly part towards (ill.BRET he should have advised him to improve his coloring, or add to his knowledge of light and shade, of which, by-thebye, he knows as little as ever did the cultivator of the tca plant 
in China. In speaking of China I might also remark, that our critic's ideas of painting are quitc in unison with those of the Chinese; for they, too, can acknowledge the good effect of light and shade and find fault with the cause.

'A Ruin, HamirToN [123]. - We have said all we need say of this gentleman's productions.' If it is really the wish of our critic to ruin Hamilton as a painter he may save himself the trouble; the people of Toronto being generally to well informed to be swayed by his brainless remarks. His next criticism is a hotch-potch of painting and politics about city seals and talented Irishmen, on which ground I will leave it without further remaark, and take up the next which is a copy from Cuyp by Thomas Dixc.r. [126] 'faithful to the qualities for which that great master was eminent,' that is, if we may believe our critic, as a proof. however, he brings forward a string of remarks from some Biographical Dictionary, which in reality serves no other purpose than to show the absurdity of his own. I will now pass on to Mr. Cook's portrait of himself [1 59], which was superior to any in that collection for the effect of light and shade; and had it been drawn with as much spirit as it is colored it would have been decidedly the best portrait in the exhibition. - Mr. cook should endeavour to improve his drawings, and his pictures will become valuable as paintings. The next is a landscape by DIxcr: [ $\left.17^{2}\right]$ and decidedly the great gem of the exhibition, so says our critic, and no doubt he is an honorable man. Yet it must be admitted, that this pretended critic would have acted a more honorable part had he examined more particularly his own qualifications before he had taken it upon himself to decide upon those of others; but there will still exist enough of ignorant audacity to qualify a man for any thing.

'Portrait of a gentleman, by J. I.1Nik [10.3]. - This is a good likeness,' of Mr. Sutherland and very prettily painted. This is, if our critic would by any possibility be esteemed a judge

'Portrait of a lady by G.S. Gilbert - a very agrceable picturc of a very beautiful young lady [188].' There is affectation in the attitude of this picture which, according to Sir Joshua RI:YNOLDS is the most hateful of all hateful qualities.

'Two portraits also by Gilbert - both admirable likenesses and skilfully painted pictures.' A few words more and I have done. It is said that wisdom is in the wig, and here it is verified with a vengeance; for, without doubt, it has never strayed beyond the precincts of our critic's wig; at least it has not in one single instance been communicated to the public by means of his pen. He now tacks down the tail of his criticisms with a latin proof of his classical education to prevent, I suppose, their blowing away in the wind. This last attempt at giving weight to his remarks brings to my mind a certain king of pedantic memory, that could repeat whole verses in that language of his own composition to; and what was he after all, but a fool. - Our critic at last takes a very affectionate leave of the gentleman artists for the present season, hoping that they will take for granted the justice of his remark, secing that his principal motive is that of encouraging the arts by cherishing the artists. We have at least (says he) satisfied our own conscience, which I have no doubt will be acknowledged for an absolute fact. And facts are chiels that winna ding an'downa de disputed.

I would stop here, Mr. Editor, but the last few lines I sent you have been attacked through "Ihe Patriot' by a person who seems to value a little too highly his external knowledge of the art, which in fact, extends no farther than the mere knowledge of the artists' names, and the number of historical subjects painted by them, and which may be had any day by applying to biographical dictionaries or other works on paint- ing. It must be admitted, however, that by the time I had got to the end of his first sentence I began to look out for a severe drubbing; all in consequence of him using that ominous word external, which, I suppose, precedes internal; and to tell the truth I was not prepared for a philosophical attack. Yet though my heart received a dirrcl at the first offset. I read on to where he blames me for an 'unwarrantable' attack upon a 'deserving young artist at present absent from the city; of which circumstance it would appear I have taken the advantage. Now, if my opponent of the pen suspects that I would watch the opportunity of taking any such cowardly advantage, let me tell him, that a man who attacks another on proper grounds has no rcason to fear either the absence or presence of his cnemies. And be it also known to this staunch supporter of the 'deserving' that I took not the trouble to enquire, and therefore was not acquainted with his friend's absence. With regard to what immediately follows I will pass it over on the ground that every sensible person will treat it as the mere assertions of an individual not qualified to dispute the point. In short, after quoting my remarks on Gilbert's works he commences in a regular and methodical manner to disect them, not however until he has condemned them as the "low abuse of an individual, and not the gentlemanly language of a critic, or person conversant in the art.' Mr. G. when he copied from prints had the same inserted in the catalogue of the exhilbition.' Quite a mistake; there is not fewer than three of his copies in one page all set down as originals. - So much for passing off, \&c. "And if he thinks it a crime (continucs the critic) to have copied from others, let me tcll him, that Michael Angelo, Leonardo da Vinci, Pietro, Perugino, Raffaelle, Bartolomeo, Andrea del Sarto, Il Rosso, and Pierino del Vago, thought it none, nor have the artists of a more modern school; and even Raffaclle went so far as to copy and pass off for his own certain figures of Masaccio; but I suppose all this will be heathen greek to the writer in The Correspondent. as it is likely hc never heard of such persons.' Now what objections can this conceited gentleman have, though I should direct the public attention on to the very page from whence he stole all these difficult names. If I mistake not it will be found in that little work on painting, by Sir Joshua Reynolds in his 12 th discourse, \&c. So much for HIS heathen greek, and extensive information. I would also have this writer to understand that I approve of quotations only on two conditions; in the first place, I would have a quotation to be properly applied - and in the next place, I would have the writer to acknowledge it; neither of which my opponent in The Patriot has attended to: but people are not to be led astray by his equivocal nonsense; and to be done with him I will tell him, that the copying from others is not by me considered a crime, but the passing off for originals, \&c. He blames Raffaelle too for attempting to deceive the public, which is, in fact, acknowledging the truth of my statement. Mr. G. merely draws heads and his method of doing so is partly mechanical. In this his friend can see no reason to find fault with him, 'especially when be it known to this sapient critic, that Sir T. Lawrence in the whole course of his long and glorious career never attempted above four historical subjects, but merely drew heads.' For what reason he has here brought forward Sir T. Lawrence and his four historical subjects I know not, since I cannot see what Mr. G's heads and historical subjects have to do with each other. Besides he has said nothing about Sir T's historical and other portraits, which were not merely heads but in many instances had hands and feet introduced. Is this like a man conversant in the art? To support this argument a little farther he brings forward another list of artists' names in the shape of Jackson, Shee, Beechy, Phillips, Peekersgill and various others, which 
according to this writer, merely drew or draws hands. Here again he must stand corrected as I could mention the name of a gentleman of this same city, now in possession of a print after shrt., in which is not only a head, but to his utter dismay, IW( BANDS. $\Lambda$ nd I will also direct his attention to that beautiful picture by l'eekersgill of an Italian female playing upon the guitar, but in case our sage writer has not yet been 'blessed with a sight of that picture' I have to inform him that it would be no easy matter to represent a female playing upon that instrument without introducing the hands - as to the mechanical method of doing it, Mr. G. uses no other mechanical means than that employed by other artists.' This is actually encouraging his friend in that which no man of real genius would descend to. He also wishes to know whether I will tell the public how many heads below 20 years of age Mr. (; has painted. But as he has made that known to the public by stating that he never painted but one, I take it for granted that his practice is not great, and, of course, there is a widc field open for his improvement, which I hope he will take the advantage of. 'And now for the climax, when a man descends in talking or writing about pictures, to introduce brick-dust, he shews at once how littlc of gentlemanly feeling or knowledge of the art pervades what he says or writes.' As to the brick-dust herc mentioned be it known that I have too much respect for the technicalities of the art to have applied them in cvery instance against such a jumble of nonsense. - He also talks of genllemanly feeling - but let me tell him that the person or persons who attempt by unjust means to exalt any man, however deserving, at the expence of others equally so in cvery respect, are no gentlemen; and if any of the lcading characters in the society of artists (Ciapt. Bonnycastle cxcepted) can find a similarity to their own conduct in the above hints they are at libcrty to make the best of it. My opponent of The Patriot now thinks it time to sound a parley on condition that I will not attack any one else in the way I have done Mr. G - but what I have said I have said, and there it must stand. As for the attack upon Mr. C. my remarks will do him infinitely more good than all that sycophantic stuff published in the Patriot, for the best of all reasons they are much nearer to the truth. With regard to our writer's knowledge of the feeling that dictated my last letter, I have only this to say, that I am as well acquainted with the cause of the one as he can be with that of the other. With this I drop the subject without any intention of returning to it, since this mere pretender in the Patriot can give me no farther information on the subject of painting than what I already know.

\section{RÉSUMÉ}

La formation de la "Society of Artists and Amateurs", la première association artistique "officielle» au Canada, témoigne de la croissance rapide de l'activité artistique à Toronto à la fin des années 1820 et au début des années 1830 . Une initiative semblable ne se répétera pas avant 1846 , avec l'inauguration des "Upper Canada Provincial Exhibitions". A l'occasion de la première et de la seule exposition, présentée en juillet 1834 dans la salle d'assemblée du troisième Parlement, les membres de la Société ainsi que des personnes de l'extérieur exposèrent des paysages pittoresques, des portraits de personnalités locales, des natures mortes, des scènes historiques et des rendus architecturaux. Le catalogue est typique des premiers catalogues d'exposition par l'absence de matériel descriptif. Par contre, les comptes rendus parus dans le Patriot et le Canadian Correspondent compensent largement cette pauvreté d'information. Non seulement nous procurent-ils une description des oeuvres, mais aussi ils démontrent l'importance des journaux locaux comme instruments de recherche. Malgré l'encouragement et l'appui fournis par le Patriot, la première société artistique de Toronto ne parvint pas à survivre comme institution permanente pour organiser des expositions d'cxuvres d'art. Les frais d'admission et les ventes du catalogue rapportèrent peu d'argent, entraînant des pertes substantielles. Parmi les professionnels qui faisaient partie de la Société, plusieurs quittèrent la ville peu de temps après, en quête d'un milieu plus favorable. En 1 847 , la "Society of Artists and Amateurs " renaissait sous le nom de "Toronto Society of Arts ». Son Comité d'administration se composait uniquement d'architectes et d'artistes professionnels qui établirent un ensemble détaillé de règles pour assurer le fonctionnement de la nouvelle société, puisque l'ancienne association de professionnels et d'amateurs n'avait tout simplement pas fonctionné. 